\title{
Oxazole-Bridged Combretastatin A-4 Derivatives with Tethered Hydroxamic Acids: Structure-Activity Relations of New Inhibitors of HDAC and/or Tubulin Function
}

\author{
Florian Schmitt ${ }^{1}$, Lisa Chiara Gosch ${ }^{2,3}$, Alexandra Dittmer ${ }^{2}$, Matthias Rothemund ${ }^{1}{ }^{(\mathbb{C},}$ \\ Thomas Mueller ${ }^{4}$, Rainer Schobert ${ }^{1}$, Bernhard Biersack ${ }^{1, *}$, Andrea Volkamer ${ }^{3} \mathbb{D}$ and \\ Michael Höpfner ${ }^{2, *}$ \\ 1 Department of Chemistry, University of Bayreuth, Universitaetsstrasse 30, 95447 Bayreuth, Germany; \\ florian1.schmitt@uni-bayreuth.de (F.S.); matthias.rothemund@uni-bayreuth.de (M.R.); \\ rainer.schobert@uni-bayreuth.de (R.S.) \\ 2 Institute of Physiology, Charité-Universitätsmedizin Berlin, Charitéplatz 1, 10117 Berlin, Germany; \\ lisa-chiara.gosch@charite.de (L.C.G.); alexandra.dittmer@charite.de (A.D.) \\ 3 In Silico Toxicology Group, Institute of Physiology, Charité-Universitätsmedizin Berlin, Charitéplatz 1, \\ 10117 Berlin, Germany; andrea.volkamer@charite.de \\ 4 Internal Medicine IV, University Hospital Halle (Saale), Ernst-Grube-Str. 40, 06120 Halle, Germany; \\ thomas.mueller@medizin.uni-halle.de \\ * Correspondence: bernhard.biersack@yahoo.com (B.B.); michael.hoepfner@charite.de (M.H.); \\ Tel.: +49-921-55-2673 (B.B.); +49-030-450-528-515 (M.H.)
}

Received: 21 December 2018; Accepted: 14 January 2019; Published: 17 January 2019

\begin{abstract}
New inhibitors of tubulin polymerization and/or histone deacetylase (HDAC) activity were synthesized by attaching alkyl tethered hydroxamic acid appendages of varying length to oxazole-bridged combretastatin A-4 analogous caps. While their antiproliferative and microtubule disrupting effect was most pronounced for derivatives with short spacers, HDAC inhibition was strongest for those with longer spacers. These findings were further supported by computational methods such as structure-based docking experiments exploring the target interactions of the derivatives with varying linkers. For instance, compounds featuring short four-atom spacers between cap and hydroxamic acid inhibited the growth of various cancer cell lines and human endothelial hybrid cells with $\mathrm{IC}_{50}$ values in the low nanomolar range. In line with their ability to inhibit the microtubule assembly, four- and five-atom spacered hydroxamic acids caused an accumulation of 518A2 melanoma cells in G2/M phase, whereas a compound featuring a six-atom spacer and performing best in HDAC inhibition, induced a G1 arrest in these cells. All these beneficial anticancer activities together with their selectivity for cancer cells over non-malignant cells, point out the great potential of these novel pleiotropic HDAC and tubulin inhibitors as drug candidates for cancer therapy.
\end{abstract}

Keywords: combretastatin A-4; oxazole; histone deacetylase; tubulin; anticancer agents

\section{Introduction}

Histone deacetylases (HDAC) catalyze the deacetylation of $\varepsilon-N$-acetyl lysine residues of histones thus regulating the expression of genes which are important for crucial cellular processes such as chromatin condensation and decondensation (DNA replication, transcription, and repair). Certain HDAC enzymes also modify non-histone proteins such as signal transduction mediators, transcription factors and regulators, as well as structural proteins resulting in modulation of cell growth, differentiation, migration, and angiogenesis [1]. HDACs are overexpressed in various solid tumors, e.g., in gastric cancer, prostate 
cancer, breast cancer, and colorectal cancer [2-6]. HDAC of class I (HDAC1, 2, 3, and 8), class Ila (HDAC4, 5, 7, and 9), class Ilb (HDAC6, and 10) and class IV (HDAC11) share a zinc(II) cation in the center of their catalytic cavity which is the target of several approved HDAC inhibitors (HDACi) [1]. By the development of several HDACi over the last two decades, a robust pharmacophore model for zinc-dependent HDACi was established typically consisting of a zinc binding group (ZBG), a linker, and a capping group (Figure 1). These HDACi mimic the natural substrate acetyl-lysine and exert their effect by coordination of the zinc(II) center with ligands such as benzamides, carboxylates, or hydroxamic acids [7]. The ZBGs should be connected to the cap by a hydrophobic linker, which is slim enough to fit in the tunnel between the active site and the capping groups. The latter are used for surface recognition and can induce sub-class selectivity [8,9]. Several HDACi such as vorinostat (SAHA, Figure 1), belinostat (PXD101, Figure 1) and panobinostat (LBH589) which were modelled on this pharmacophore template are already approved for the therapy of lymphoma and myeloma [10-13]. Several other HDACi are recently under clinical investigation, since HDACi of the first generation have shown certain shortcomings in solid tumors such as induction of epithelial-to-mesenchymal transition (EMT) in prostate cancer cells [14-16]. In order to overcome such drawbacks, HDACi with dual or multimodal activities including kinase inhibition or DNA alkylation/metalation were introduced [17].

Microtubules are vital components of the cytoskeleton and thus an important target in cancer chemotherapy $[18,19]$. Interestingly, HDACi have shown synergetic effects when combined with tubulin-binding anticancer drugs [20-22]. Thus, HDACi harboring tubulin-targeting structural motifs appear to be promising anticancer drug candidates [23-25]. While colchicine- and quinazoline-based dual inhibitors were already published, no dual inhibitors based on the potent microtubule disrupting agent (MDA) combretastatin A-4 (CA-4, Figure 1) are known, so far. Herein, we present a new series of tubulin-targeting oxazole-bridged CA-4 derivatives with hydroxamate appendages. We chose the oxazole-bridged CA-4 scaffold because of its improved stability when compared with the cis-stilbene CA-4 parent compound $[26,27]$. We investigated how the linker length of the new hybrid compounds affects the compounds' potency to inhibit HDAC1 and HDAC6, as well as the microtubule assembly. Moreover, the anti-proliferative, anti-migratory, and further anticancer activities of the new hybrid compounds were evaluated, and computational methods were used to predict and to explain binding modes and affinities of the studied compounds.

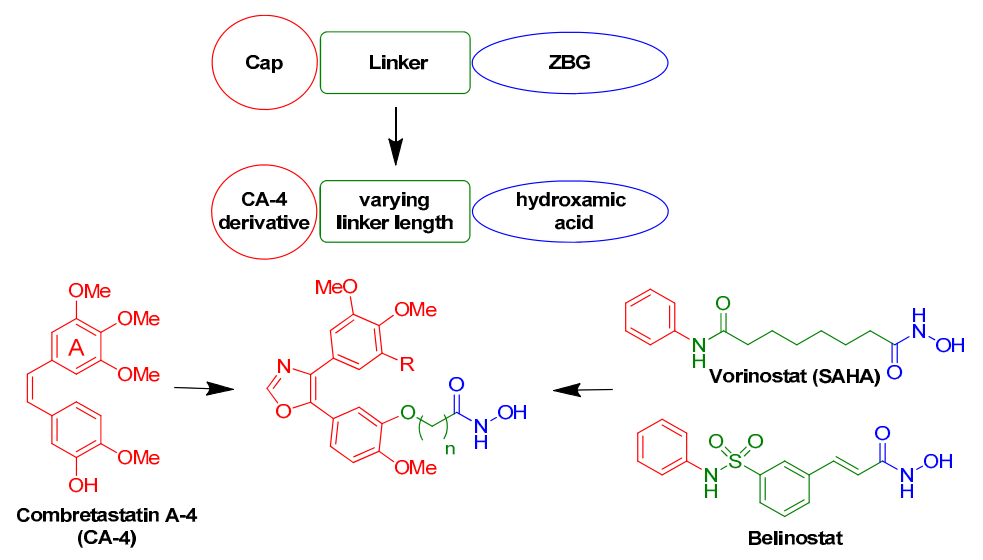

Figure 1. General pharmacophore model of HDACi, structures of the vascular-disrupting agent (VDA) combretastatin A-4 (CA-4) and of the HDACi vorinostat (SAHA) and belinostat as well as the combination of CA-4 derivatives and HDACi in our hybrid compounds.

\section{Results}

\subsection{Chemistry}

The 4,5-diaryloxazoles were synthesized via a Van Leusen reaction. The required starting benzaldehydes $\mathbf{1 a}-\mathbf{c}$ and TosMIC reagents $\mathbf{2 a -}-\mathbf{c}$ were prepared according to literature procedures, 
i.e., the former via alkylation of isovanillin with the corresponding ethyl $\omega$-bromoalkanoates, and the latter via dehydration of their tosylmethyl formamide precursors (obtained from reaction of 3-bromo/chloro-4,5-dimethoxybenzaldehyde or 3,4,5-trimethoxybenzaldehyde with toluenesulfinic acid and formamide) [25-28]. The synthesis of the target hydroxamic acids $4 \mathbf{a}-\mathbf{i}$ was carried out in two steps. Van Leusen reaction of $\mathbf{1 a}-\mathbf{c}$ and $\mathbf{2 a}-\mathbf{c}$ gave the oxazoles $\mathbf{3 a} \mathbf{a}-\mathbf{i}$ in moderate yields (Scheme 1). Conversion of the ethyl esters $\mathbf{3 a - i}$ to the analogous hydroxamic acids $4 \mathbf{a}-\mathbf{i}$ was accomplished in moderate to high yields. The target compounds $4 \mathbf{a}-\mathbf{i}$ were obtained as colorless solids. In addition, carboxylic acid analog $4 \mathbf{j}$ was prepared for comparison purposes and obtained from hydrolysis of $\mathbf{3} \mathbf{g}$ under basic conditions (Scheme 1).
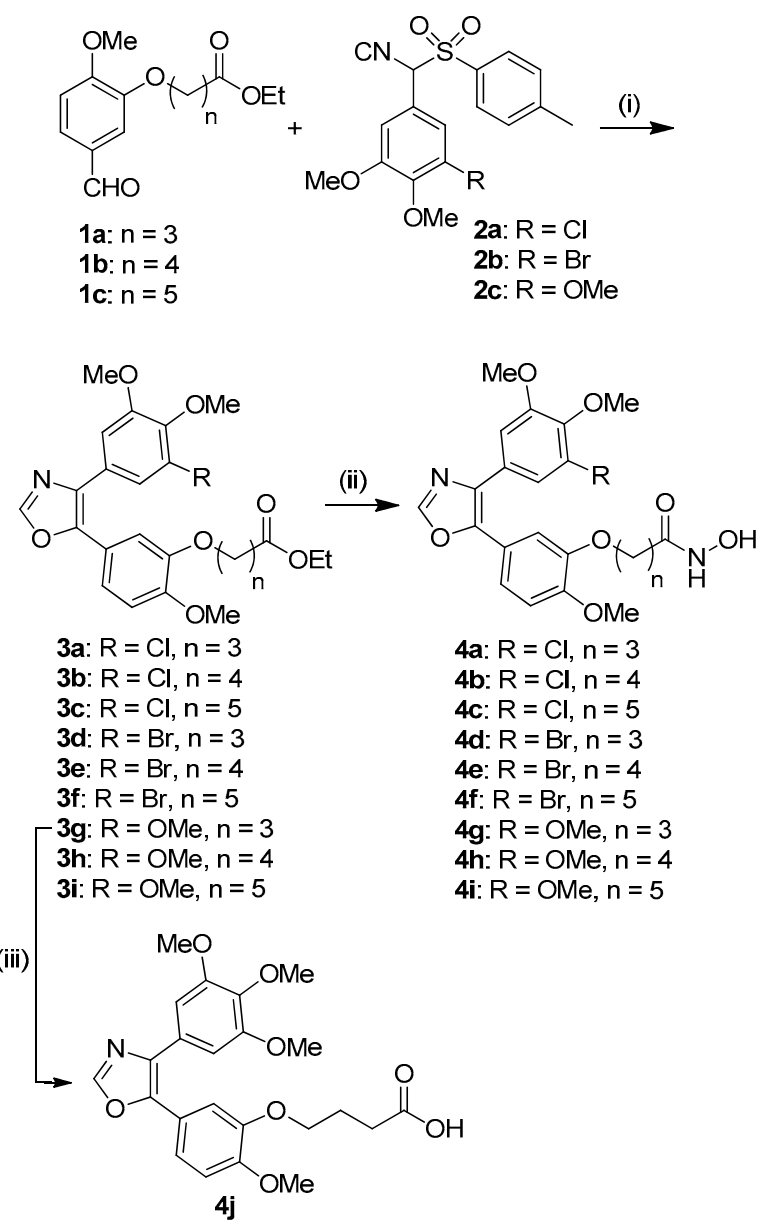

4a: $\mathrm{R}=\mathrm{Cl}, \mathrm{n}=3$

4b: $\mathrm{R}=\mathrm{Cl}, \mathrm{n}=4$

4c: $\mathrm{R}=\mathrm{Cl}, \mathrm{n}=5$

4d: $\mathrm{R}=\mathrm{Br}, \mathrm{n}=3$

4e: $R=B r, n=4$

4f: $R=B r, n=5$

4g: $\mathrm{R}=\mathrm{OMe}, \mathrm{n}=3$

4h: $\mathrm{R}=\mathrm{OMe}, \mathrm{n}=4$

4i: $R=O M e, n=5$

(iii)

Scheme 1. Reagents and conditions: (i) $\mathrm{K}_{2} \mathrm{CO}_{3}, \mathrm{EtOH}$, reflux, $2 \mathrm{~h}, 40-53 \%$; (ii) $50 \% \mathrm{H}_{2} \mathrm{~N}-\mathrm{OH}$ in $\mathrm{H}_{2} \mathrm{O}$, $\mathrm{NaOH}, \mathrm{CH}_{2} \mathrm{Cl}_{2} / \mathrm{MeOH}(1: 2)$, r.t., 1 h, 64-93\%; (iii) $1 \mathrm{M}$ aq. $\mathrm{NaOH}, \mathrm{MeOH}$, r.t., 24 h, $68 \%$.

\subsection{Biological Evaluation}

First, all compounds $(\mathbf{4} \mathbf{a}-\mathbf{j})$ were tested for their growth inhibitory potential in cancer cell lines. The new derivatives $\mathbf{4 a}-\mathbf{i}$, the new carboxylic acid analog $4 \mathbf{j}$ and its ethyl-ester $\mathbf{3 g}$ were screened in MTT assays for anti-proliferative activity against a panel of six cancer cell lines of four entities as well as against the human endothelial hybrid cell line Ea.Hy926 (Table 1). The bromo derivatives $\mathbf{4} \mathbf{d}-\mathbf{f}$ were also tested against the non-malignant human dermal fibroblasts $\mathrm{HDFa}$. $\mathrm{IC}_{50}$ values of the known HDACi SAHA and the VDA CA-4 were taken from earlier studies for comparison. Compounds 4a-i led to dose-dependent growth inhibition of all cancer cell lines and the endothelial hybrid cells Ea.Hy926. Carboxylic acid $\mathbf{4 j}$ and its ester $\mathbf{3 g}$ did not affect the viability of 518A2 melanoma and HT-29 colon carcinoma cells even at concentrations as high as $50 \mu \mathrm{M}$, which suggests that the hydroxamate side chain is crucial for the anti-proliferative activity. 
Table 1. Inhibitory concentrations $\mathrm{IC}_{50}{ }^{1}(\mu \mathrm{M})$ of $\mathbf{3 g}, \mathbf{4} \mathbf{a}-\mathbf{j}$, SAHA, and CA-4 in cancer cells.

\begin{tabular}{|c|c|c|c|c|c|c|c|c|c|c|}
\hline & 518A2 (24 h) & 518A2 (72 h) & HT-29 (24 h) & HT-29 (72 h) & DLD-1 (72 h) & HCT-116 $(72$ h) & KB-V1 ${ }^{\mathrm{Vbl}}(72 \mathrm{~h})$ & MCF-7 ${ }^{\text {Topo }}$ (72 h) & Ea.Hy926 (72 h) & HDFa (72 h) \\
\hline $3 g$ & $>100$ & $>50$ & $>100$ & $>50$ & $-c$ & - & - & - & - & - \\
\hline $4 a$ & $1.3 \pm 0.4$ & $0.11 \pm 0.01$ & $2.5 \pm 0.4$ & $2.9 \pm 0.3$ & $0.34 \pm 0.01$ & $0.21 \pm 0.01$ & $0.15 \pm 0.02$ & $0.66 \pm 0.14$ & $0.0012 \pm 0.0006$ & - \\
\hline $4 b$ & $10.4 \pm 5.1$ & $1.0 \pm 0.1$ & $4.2 \pm 0.2$ & $3.6 \pm 0.1$ & $3.2 \pm 0.1$ & $2.4 \pm 0.1$ & $4.0 \pm 0.2$ & $2.9 \pm 0.8$ & $0.57 \pm 0.07$ & - \\
\hline $4 c$ & $9.4 \pm 1.4$ & $2.2 \pm 0.3$ & $4.6 \pm 0.3$ & $4.9 \pm 0.3$ & $3.3 \pm 0.5$ & $6.5 \pm 0.3$ & $18.4 \pm 3.4$ & $6.1 \pm 0.7$ & $7.5 \pm 0.5$ & - \\
\hline $4 d$ & $0.71 \pm 0.05$ & $0.11 \pm 0.01$ & $1.3 \pm 0.3$ & $1.4 \pm 0.2$ & $0.29 \pm 0.02$ & $0.13 \pm 0.01$ & $0.48 \pm 0.06$ & $2.8 \pm 0.3$ & $0.018 \pm 0.004$ & $23.9 \pm 1.6$ \\
\hline $4 e$ & $2.4 \pm 0.3$ & $0.80 \pm 0.07$ & $2.1 \pm 0.6$ & $1.9 \pm 0.2$ & $2.1 \pm 0.4$ & $2.2 \pm 0.3$ & $2.0 \pm 0.3$ & $3.4 \pm 0.2$ & $0.66 \pm 0.01$ & $>100$ \\
\hline $4 f$ & $7.6 \pm 0.2$ & $6.4 \pm 0.4$ & $6.6 \pm 0.6$ & $14.2 \pm 1.6$ & $4.1 \pm 0.3$ & $6.3 \pm 0.4$ & $7.1 \pm 0.2$ & $8.3 \pm 0.7$ & $0.41 \pm 0.04$ & $>50$ \\
\hline $4 \mathrm{~g}$ & $4.4 \pm 0.1$ & $0.64 \pm 0.07$ & $5.0 \pm 0.2$ & $2.8 \pm 0.2$ & $0.92 \pm 0.04$ & $0.92 \pm 0.12$ & $2.7 \pm 0.2$ & $9.3 \pm 0.8$ & $0.41 \pm 0.04$ & - \\
\hline $4 \mathrm{~h}$ & $21.6 \pm 3.9$ & $5.6 \pm 0.6$ & $53.9 \pm 12.0$ & $6.6 \pm 0.6$ & $5.8 \pm 0.4$ & $3.4 \pm 0.4$ & $11.1 \pm 1.6$ & $39.6 \pm 5.9$ & $3.4 \pm 0.2$ & - \\
\hline $4 i$ & $6.9 \pm 2.5$ & $3.3 \pm 0.3$ & $47.6 \pm 10.6$ & $1.7 \pm 0.1$ & $1.3 \pm 0.1$ & $0.61 \pm 0.07$ & $9.0 \pm 0.3$ & $15.8 \pm 1.4$ & $1.7 \pm 0.1$ & - \\
\hline $4 \mathbf{j}$ & $>100$ & $>50$ & $>100$ & $>100$ & - & - & - & - & - & - \\
\hline SAHA $^{2}$ & $18.7 \pm 0.1$ & $1.8 \pm 0.1$ & $1.9 \pm 0.3$ & $1.8 \pm 0.1$ & - & $0.9 \pm 0.1$ & $13.1 \pm 0.8$ & $13.5 \pm 0.7$ & $1.9 \pm 0.2$ & - \\
\hline $\mathrm{CA}-4^{2}$ & - & $0.018 \pm 0.007$ & - & $3.6 \pm 0.1$ & - & $0.0026 \pm 0.0002$ & - & $0.50 \pm 0.20$ & $0.011 \pm 0.002$ & - \\
\hline
\end{tabular}

${ }^{1}$ Values are derived from dose-response curves obtained by determining the percentage of viable cells (human 518A2 melanoma, HT-29, HCT-116 and DLD-1 colon carcinomas, KB-V1 1 Vbl cervix carcinoma, and MCF-7 ${ }^{\text {Topo }}$ breast adenocarcinoma as well as to Ea.Hy926 endothelial hybrid cells and non-malignant HDFa dermal fibroblasts) relative to vehicle treated controls after $24 \mathrm{~h}$ or $72 \mathrm{~h}$ treatment with the test compounds using MTT-assays; values are the means \pm SD of four independent experiments. ${ }^{2}$ Values taken from earlier publications, ref 27,33 , and $34 .{ }^{c}-=$ not determined. 
On average, the CA-4 resistant HT-29 colon carcinoma and the multi-drug resistant MCF-7Topo mamma carcinoma cells were least sensitive to $4 \mathbf{a}-\mathbf{i}[29,30]$. In contrast, $4 \mathbf{a}-\mathbf{i}$ were most active against 518A2 melanoma, HCT-116 colon carcinoma, and endothelial hybrid cells Ea.Hy926. The low $\mathrm{IC}_{50}$ values of the compounds 4a-i against Ea.Hy926 cells are indicative of a potential application as a vascular disruptive agent like the parent CA-4. Moreover, the bromo substituted derivatives $4 \mathbf{d}-\mathbf{f}$ showed a distinct selectivity for cancer and endothelial cells over non-malignant human dermal fibroblasts HDFa. The chloro substituted compounds $\mathbf{4 a - c}$ and the bromo substituted compounds $\mathbf{4 d}-\mathbf{f}$ showed an interesting structure-activity relationship (SAR). The anti-proliferative activity increased with decreasing linker length when going from caproic acid derivatives $4 \mathrm{c}$ and $4 \mathrm{f}$ over valeric acid derivatives $4 \mathrm{~b}$ and $4 \mathrm{e}$ to butyric acid derivatives $4 \mathrm{a}$ and $4 \mathrm{~d}$. Interestingly, the trimethoxy derivatives $\mathbf{4 g}-\mathbf{i}$ did not fit in this SAR since $4 \mathbf{i}$ was on average more cytotoxic than $4 \mathbf{h}$. Several earlier studies had shown that the substitution of an $m$-methoxy group at the A-ring of CA-4 derivatives by halide increases their activity. We now observed a similar phenomenon since the chloro substituted derivatives $\mathbf{4 a - c}$ and the bromo substituted analogs $4 \mathbf{d}-\mathbf{f}$ were superior to the trimethoxy derivatives $\mathbf{4 g}-\mathbf{i}$. Additionally, we determined the $\mathrm{IC}_{50}$ values of the test compounds when applied to 518A2 melanoma cells for different incubation periods ( 24 and $72 \mathrm{~h}$ ). In the case of the most strongly anti-proliferative compounds $(\mathbf{4 a}, \mathbf{4 d}$, and $\mathbf{4 g})$, the $\mathrm{IC}_{50}$ values after $72 \mathrm{~h}$ were about eight-fold lower compared with those after $24 \mathrm{~h}$. Since most of the investigated cell lines have division periods of 20-30 h, we assume that the test compounds exert their effect by blocking the cell division and by triggering apoptosis [31,32]. Earlier publications by our group disclosed a significant tumor selectivity of the control compounds SAHA and CA-4 (i.e., low activity against CHF/chicken heart fibroblast cells) which can explain the observed tumor selectivity of compounds $4 \mathbf{d}-\mathbf{f}[33,34]$.

Next, we investigated how the length of the linker of the test compounds may influence cytoskeletal components, the inhibition of HDAC1 and HDAC6, and cell cycle progression. These analyses were performed only with the bromo substituted derivatives $\mathbf{4 d} \mathbf{d} \mathbf{f}$ which showed slightly higher anti-proliferative activity on average compared to their chloro or methoxy congeners. At first, the new hybrid compounds $4 \mathbf{d}-\mathbf{f}$ were tested for their potential inhibition of the microtubule assembly, which is a typical feature of the parent compound CA-4. MTT assays already revealed some CA-4 characteristics such as selectivity for EA.Hy926 endothelial hybrid cells and a reduced efficacy against HT-29 colon carcinoma cells [33]. The effect of the test compounds on the polymerization of tubulin was determined in vitro using purified pig brain tubulin (Figure 2). An amount of $10 \mu \mathrm{M}$ of $\mathbf{4} \mathbf{d}$ inhibited the polymerization of pig brain tubulin nearly completely, while $\mathbf{4 e}$ exhibited a merely moderate inhibitory effect and $\mathbf{4 f}$ virtually none.

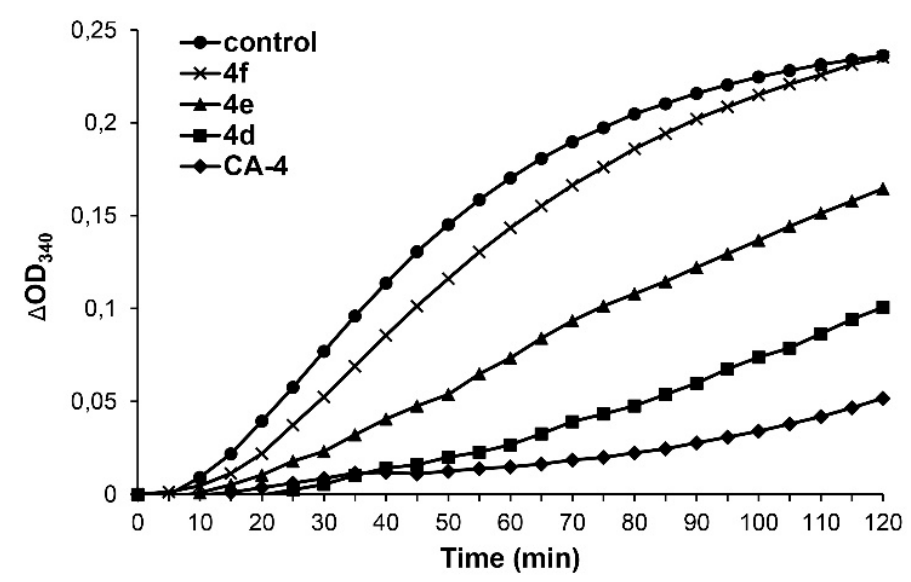

Figure 2. Effects of compounds $4 \mathbf{d}-\mathbf{f}$ and CA-4 $(10 \mu \mathrm{M})$ on the polymerization of tubulin as determined by a turbidimetric cell-free tubulin assay. Data are representative of three independent experiments. $\Delta \mathrm{OD}_{340}$ is the change in the absorption at $340 \mathrm{~nm}$ wavelength with $\mathrm{OD}_{340}$ set as 0 at $0 \mathrm{~min}(p \leq 0.001$ for CA-4 and $4 \mathbf{d}$ compared to controls, one-tailed Dunnett post-hoc test). 
These results are in line with the anti-proliferative activity pattern of the compounds and were additionally confirmed on a cellular level by immunostaining of alpha-tubulin in 518A2 melanoma cells (Figure 3). Caproic acid derivative $4 \mathbf{f}$, showing the highest $\mathrm{IC}_{50}$ values in MTT assays, did not affect the microtubule cytoskeleton even at concentrations as high as $4 \mu \mathrm{M}$. In contrast, $4 \mathrm{e}$ eroded the highly organized microtubule network, but left some intact clusters especially around the nuclei whereas $0.5 \mu \mathrm{M}$ of $4 \mathbf{d}$ was enough to cause a complete disruption of the microtubule cytoskeleton. Similar alterations of the cytoskeleton of endothelial Ea.Hy926 cells were observed upon treatment with $0.2 \mu \mathrm{M}$ of $4 \mathbf{d}$ for $24 \mathrm{~h}$ (Figure S1, Supporting Information). The deacetylation of tubulin by compounds $\mathbf{4 d}$ and $\mathbf{4 f}$ is presented below. In addition, elevated levels of reactive oxygen species (ROS, Figure S2, Supporting Information), which are known to trigger apoptosis and reverse chemoresistance in tumors, were observed in 518A2 melanoma cells (4d: $241 \% \pm 17$; 4e: $230 \pm 31$; 4 f: $198 \pm 24$ ). Again, as already observed for anti-proliferative activity the ability to elevate ROS levels decreases with increasing linker length.

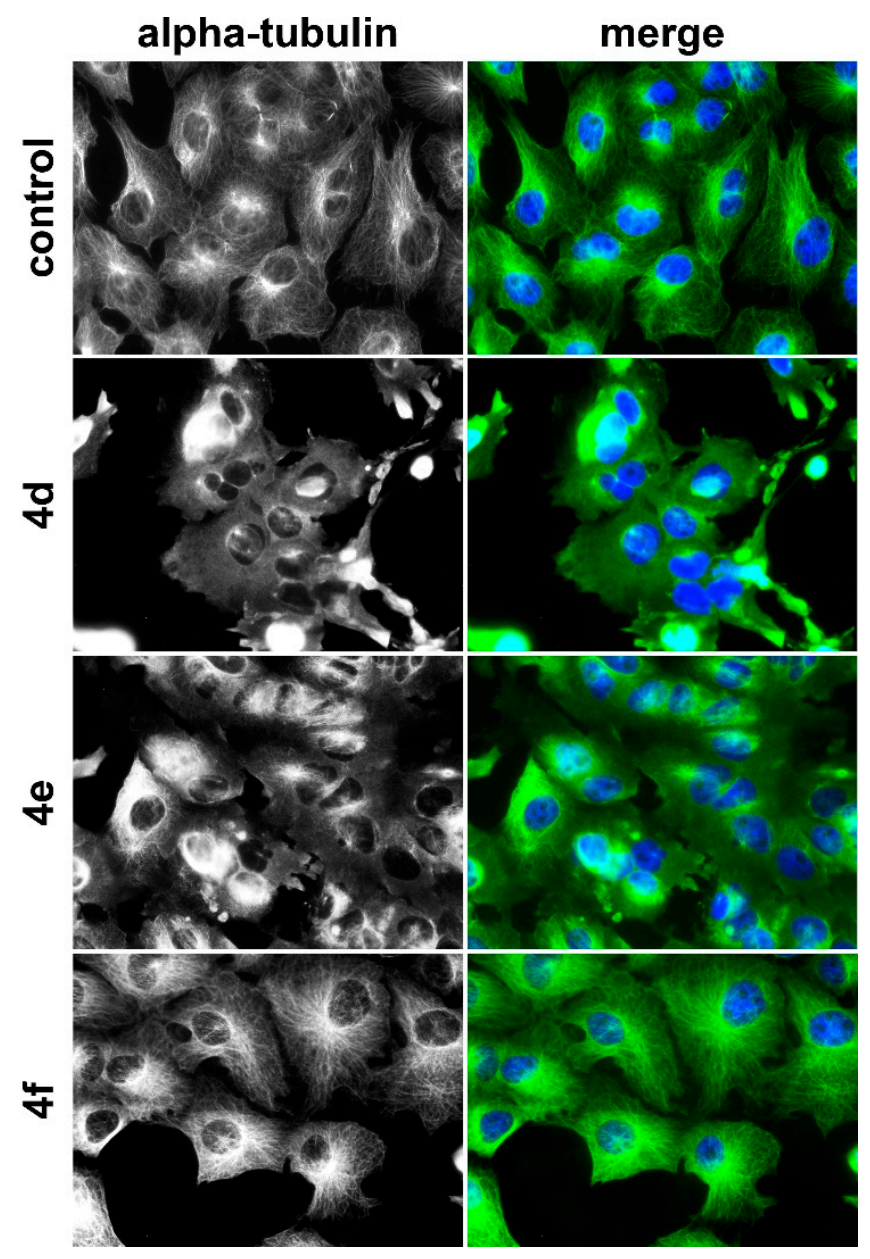

Figure 3. Effect of compounds $4 \mathrm{~d}(0.5 \mu \mathrm{M}), 4 \mathrm{e}(1.5 \mu \mathrm{M}), 4 \mathrm{f}(4 \mu \mathrm{M})$, and vehicle (DMSO) on the organization of microtubule cytoskeleton in 518A2 melanoma cells after $24 \mathrm{~h}$ incubation. Nuclei were counterstained with DAPI (merge, blue); microtubule (green). Pictures are representative of two independent experiments $(400 \times$ magnification).

We also investigated the bromo derivatives $\mathbf{4 d} \mathbf{d} \mathbf{f}$ with different linker lengths for their inhibitory effect on the deacetylation capacity of recombinant human HDAC1 and HDAC6 (Table 2). Contrary to the inhibition of tubulin polymerization and cell proliferation, which decreased with growing linker length, the HDAC inhibition increased with linker length. Compound $4 \mathbf{d}$, the most cytotoxic compound in this row featuring a four-atom spacer, showed only moderate HDAC6 inhibition (IC ${ }_{50}$ : $13.8 \pm 0.2$ 
$\mu \mathrm{M})$. Compound $4 \mathbf{e}$, carrying a five-atom linker, had a distinctly lower $\mathrm{IC}_{50}$ value $(3.5 \pm 0.1 \mu \mathrm{M})$, whereas $4 \mathbf{f}$, the compound with a six-atom linker, had the lowest $\mathrm{IC}_{50}$ value of this triad $(0.32 \pm 0.02$ $\mu \mathrm{M})$, which was even slightly lower than that of the known HDAC6 selective inhibitor tubacin $(0.38 \pm$ $0.03 \mu \mathrm{M})$. Concerning HDAC1 inhibition, $4 \mathbf{d}$ and $4 \mathbf{e}$ showed similar $\mathrm{IC}_{50}$ values $(4.0 \pm 0.1$ and $3.8 \pm$ $0.1 \mu \mathrm{M})$ whereas $4 \mathrm{f}$ was again the most potent compound $(0.49 \pm 0.05 \mu \mathrm{M})$. Unlike HDAC1 which is found in the nucleus of cells where it is responsible for the eponymous deacetylation of histones, HDAC6 locates predominantly in the cytoplasm and has several targets including $\alpha$-tubulin, HSP90, cortactin, and $\beta$-catenin $[35,36]$. The inhibition of HDAC6 induces hyperacetylation of these molecules resulting in a reduction of cell motility, and proliferation, and eventually induces cell death [37]. The ability of compound $4 \mathbf{f}$ to inhibit HDAC6 was confirmed by western blot analyses (Figure 4) as well as by immunofluorescence staining of acetyl-alpha-tubulin in 518A2 melanoma cells (Figures S3 and S4, Supporting Information). In both experiments, treatment of the cells with $4 \mathrm{f}$ caused a distinct increase of acetyl-alpha-tubulin. Thus, a distinct difference between $\mathbf{4 d}$ and $\mathbf{4 f}$ concerning their effects on the microtubule cytoskeleton became visible. While $4 \mathrm{~d}$ destroys the microtubules in line with its high tubulin polymerization inhibitory activity, $4 \mathrm{f}$ did not destroy the microtubules yet enhanced the acetylation grade of microtubules due to its strong HDAC6 inhibition.

Table 2. HDAC inhibition $\left[\mathrm{IC}_{50}(\mu \mathrm{M})\right]^{1}$ by compounds $4 \mathbf{d}-\mathbf{f}$.

\begin{tabular}{cccccc}
\hline & $\mathbf{4 d}$ & $\mathbf{4 e}$ & $\mathbf{4 f}$ & SAHA & Tubacin \\
\hline HDAC1 & $4.0 \pm 0.1$ & $3.8 \pm 0.1$ & $0.49 \pm 0.05$ & $0.44 \pm 0.04$ & - \\
HDAC6 & $13.8 \pm 0.2$ & $3.5 \pm 0.1$ & $0.32 \pm 0.02$ & $0.15 \pm 0.004$ & $0.38 \pm 0.03$ \\
\hline
\end{tabular}

${ }_{1} \mathrm{IC}_{50}$ values are derived from dose-response curves obtained by measuring the percentage of deacetylated, fluorogenic substrate relative to DMSO controls. Results show inhibition of recombinant HDAC1 and HDAC6 by compounds $4 \mathbf{d}-\mathbf{f}$, pan-HDAC inhibitor SAHA and HDAC6-specific inhibitor tubacin as determined by conversion of a HDAC substrate to a fluorophore. Values are the means \pm SD of two independent experiments.

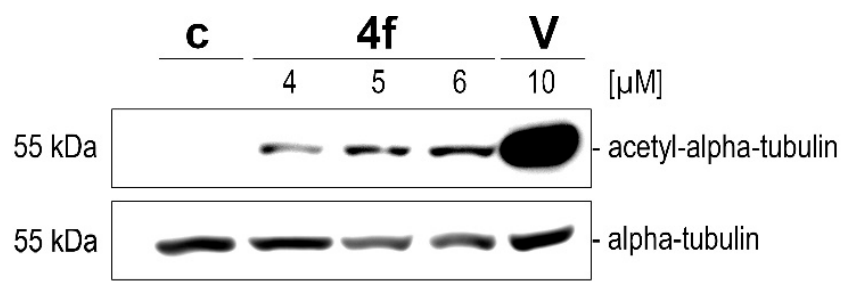

Figure 4. Compound-induced effect on the acetylation of microtubules (acetyl-alpha-tubulin) in 518A2 melanoma cells upon treatment with $4 \mathrm{f}(4,5$, and $6 \mu \mathrm{M})$, SAHA $(10 \mu \mathrm{M})$, and vehicle (DMSO) for $24 \mathrm{~h}$. Cells were lysed and the levels of the acetyl-alpha-tubulin was monitored by immunoblotting with the specific antibody. c: control; V: SAHA/vorinostat.

Imidazole-bridged CA-4 derivatives carrying hydroxamic acid appendages had previously been found to induce alterations of the actin cytoskeleton, such as augmented formation of stress fibers to the effect of an impaired cell motility [34,38]. Such alterations are typical reactions to microtubule destabilization and hyperacetylation of cortactin as a consequence of HDAC6 inhibition [39]. Thus, we investigated the bromo derivatives $4 \mathbf{d}-\mathbf{f}$ for their effect on the actin cytoskeleton of 518A2 melanoma cells (Figure 5). Even though their effects on the microtubules of these cells differed, all of them induced the formation of actin stress fibers which traversed the whole cell body, while the control cells showed only filamentous actin in the periphery. The associated anti-migratory effects of compounds $\mathbf{4 d}-\mathbf{f}$ were then tested in so-called wound healing assays. In this assay a strip of cells is scratched off a confluent grown cell monolayer of 518A2 cells, followed by monitoring the gap-closing process operating not by proliferation but by active migration (Figures S5 and S6, Supporting Information). The re-closure of the scratch area was significantly retarded in samples treated with compounds $4 \mathbf{d}-\mathbf{f}$ for $24 \mathrm{~h}$ (38-45\% wound closure) compared to vehicle treated control cells ( $63 \%$ wound closure). 


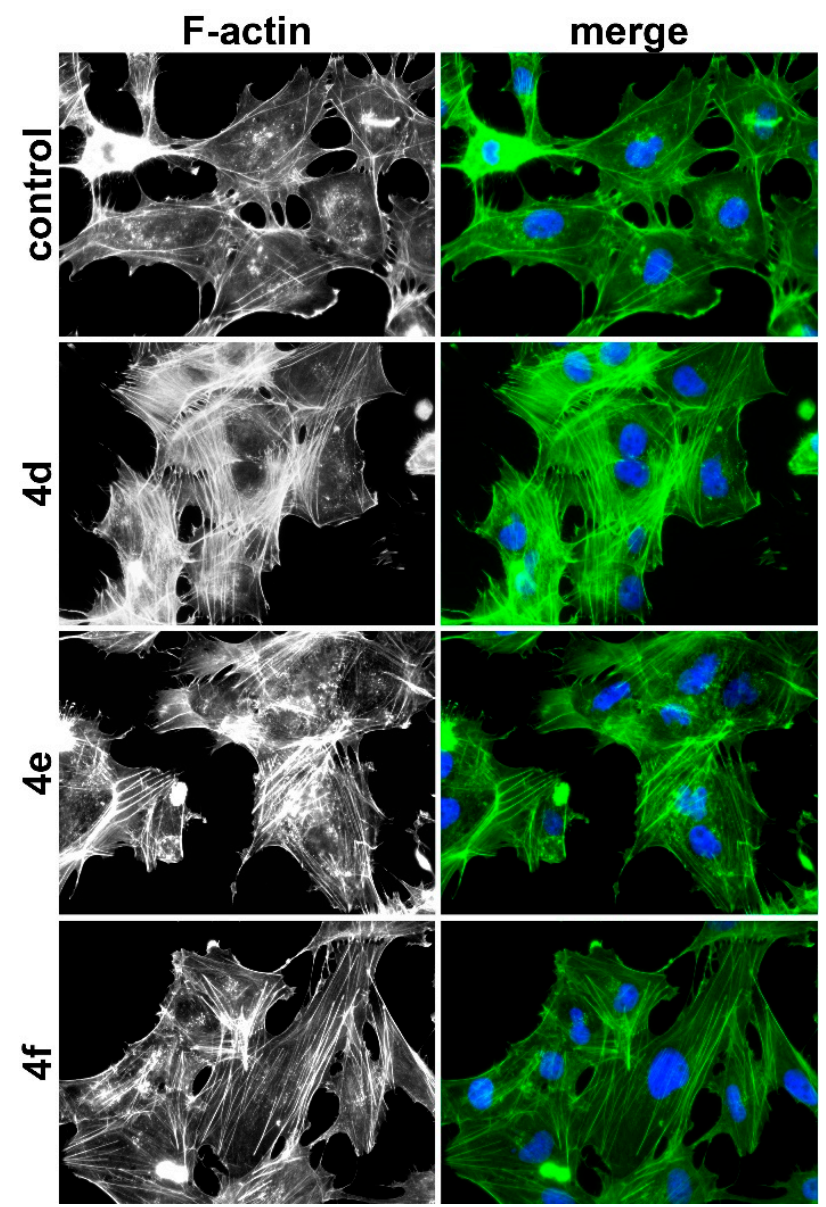

Figure 5. Effect of $4 \mathbf{d}(0.5 \mu \mathrm{M}), 4 \mathbf{e}(1.5 \mu \mathrm{M}), \mathbf{4 f}(4 \mu \mathrm{M})$, and vehicle (DMSO) on the organization of the actin cytoskeleton in 518A2 melanoma cells after $24 \mathrm{~h}$ exposure. Fluorescence labeling of filamentous actin (F-actin; green). Nuclei were counterstained with DAPI (merge, blue). Pictures are representative of two independent experiments (400× magnification).

Stress fiber formation in combination with microtubule destruction frequently leads to the arrest of cells in the G2/M phase of the cell cycle. By contrast, HDAC inhibition typically induces an arrest of cells in the G1 phase [40-45]. To investigate whether microtubule destabilization or HDAC inhibition of the test compounds $\mathbf{4 d} \mathbf{d}-\mathbf{f}$ prevails on cell cycle regulation, cell cycle arresting effects were tested in 518A2 melanoma cells by FACS analysis (Figure 6, Table 3). As expected, the strongly microtubule-destabilizing compounds $4 \mathbf{d}$ and $4 \mathbf{e}$ led to an accumulation of 518A2 cells in G2/M phase. In contrast, the stronger HDAC inhibitor $\mathbf{4 f}$, which lacks microtubule destabilizing activity, induced a G1 phase arrest in the investigated melanoma cells.

The effects of $4 \mathbf{d}$ on the cell cycle regulatory proteins p21, p27, and cyclin D1 in 518A2 melanoma cells were investigated (Figure 7). At higher doses $4 \mathbf{d}$ increased the level of cyclin D1 which was comparable with the effect on cyclin D1 by SAHA. It seems that the HDAC inhibitory properties of $4 \mathbf{d}$ at higher concentrations caused the induction of cyclin D1. In addition, $4 \mathrm{~d}$ distinctly suppressed p21 expression while SAHA showed no effects on p21. It is conceivable that the observed p21 suppression is associated with the cytoskeleton targeting of $\mathbf{4} \mathbf{d}$ which is also in line with the G2/M arrest caused by $\mathbf{4} \mathbf{d}$ in $518 \mathrm{~A} 2$ cells. In contrast to that, $\mathbf{4 f}$ seemingly upregulated p21 expression in a dose-dependent way in congruence to SAHA.

Finally, compound $4 \mathrm{~d}$ was tested concerning in vivo applicability and the toxicity of compound $\mathbf{4 d}$ to mice was investigated (Figure S7, Supporting Information). High doses of $\mathbf{4 d}(1 \times 100 \mathrm{mg} / \mathrm{kg}$ i.p., $1 \times 200 \mathrm{mg} / \mathrm{kg}$ orally) were tolerated well by the treated mice and they showed no signs of toxicity (i.e., no weight loss, weight changes of maximal 5\%, normal behavior). Thus, a more thorough in vivo 
investigation of $\mathbf{4} \mathbf{d}$ in suitable tumor xenograft models is recommended due to the manageable toxicity profile of this compound.
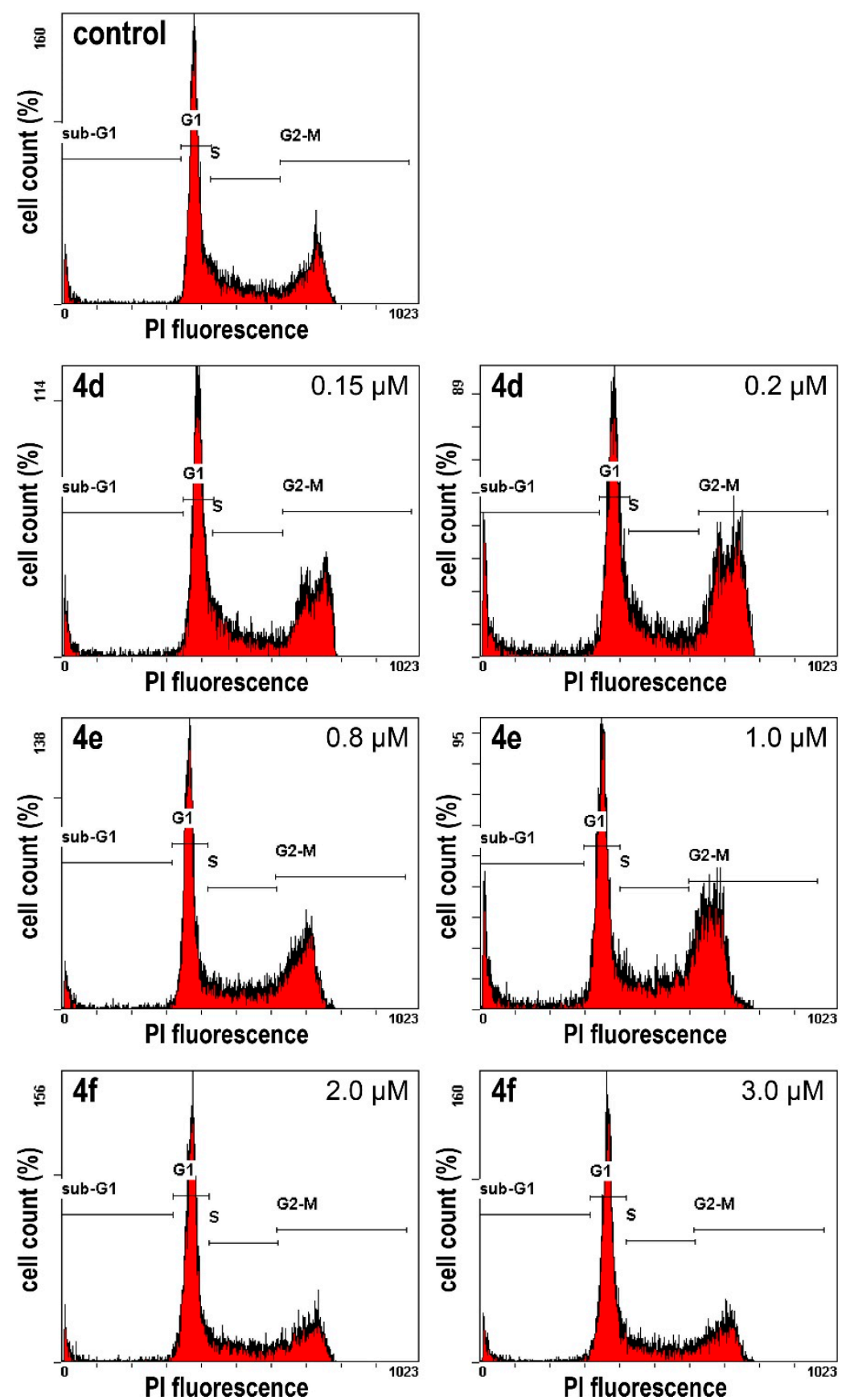

Figure 6. Effect of $4 \mathrm{~d}(0.15$ and $0.2 \mu \mathrm{M}), 4 \mathrm{e}(0.8$ and $1 \mu \mathrm{M}), 4 \mathrm{f}(2$ and $3 \mu \mathrm{M})$ or control (DMSO) on the proportions of 518A2 melanoma cells in G1, S, and G2/M phase of the cell cycle as well as the percentages of apoptotic cells in sub-G1 as determined by flow cytometry after PI staining. Cells were treated with the test compounds for $24 \mathrm{~h}$. Cell cycle profiles are representatives of at least three independent experiments ( $p \leq 0.05$ for cells in G1-phase treated with $\mathbf{4 d - f}$ compared with those of vehicle-treated controls, two-tailed Games-Howell's post-hoc test). 
Table 3. Effect of $\mathbf{4 d - 4 f}$ on the cell cycle of 518A2 melanoma cells ${ }^{1}$.

\begin{tabular}{ccccc}
\hline & Sub-G1 & G1 & S & G2/M \\
\hline Control & $4.9 \pm 2.0$ & $49.7 \pm 1.0$ & $19.3 \pm 0.9$ & $26.1 \pm 2.3$ \\
$\mathbf{4 d}(0.15 \mu \mathrm{M})$ & $8.9 \pm 1.5$ & $43.0 \pm 0.9$ & $19.2 \pm 1.4$ & $28.9 \pm 2.7$ \\
$\mathbf{4 d}(0.2 \mu \mathrm{M})$ & $14.4 \pm 2.8$ & $33.9 \pm 3.4$ & $16.3 \pm 1.1$ & $35.4 \pm 2.4$ \\
$\mathbf{4 e}(0.8 \mu \mathrm{M})$ & $5.1 \pm 1.2$ & $43.1 \pm 1.3$ & $19.2 \pm 0.7$ & $32.6 \pm 1.7$ \\
$\mathbf{4 e}(1 \mu \mathrm{M})$ & $10.8 \pm 4.4$ & $35.4 \pm 1.1$ & $19.0 \pm 0.3$ & $34.9 \pm 3.5$ \\
$\mathbf{4 f}(2 \mu \mathrm{M})$ & $5.6 \pm 0.8$ & $53.9 \pm 0.8$ & $18.3 \pm 0.7$ & $22.2 \pm 0.5$ \\
$\mathbf{4 f}(3 \mu \mathrm{M})$ & $6.3 \pm 0.9$ & $54.2 \pm 0.5$ & $16.9 \pm 0.6$ & $22.5 \pm 0.3$ \\
\hline
\end{tabular}

${ }^{1}$ Effect of $4 \mathbf{d}(0.15$ and $0.2 \mu \mathrm{M}), 4 \mathbf{e}(0.8$ and $1 \mu \mathrm{M}), 4 \mathrm{f}(2$ and $3 \mu \mathrm{M})$, or vehicle (DMSO) on the proportions of 518A2 melanoma cells in G1, S, and G2/M phase of the cell cycle as well as the percentages of apoptotic cells in sub-G1 as determined by flow cytometry after PI staining. Cells were treated with the test compound for $24 \mathrm{~h}$. Values are the means $\pm \mathrm{SD}$ of at least three independent experiments.

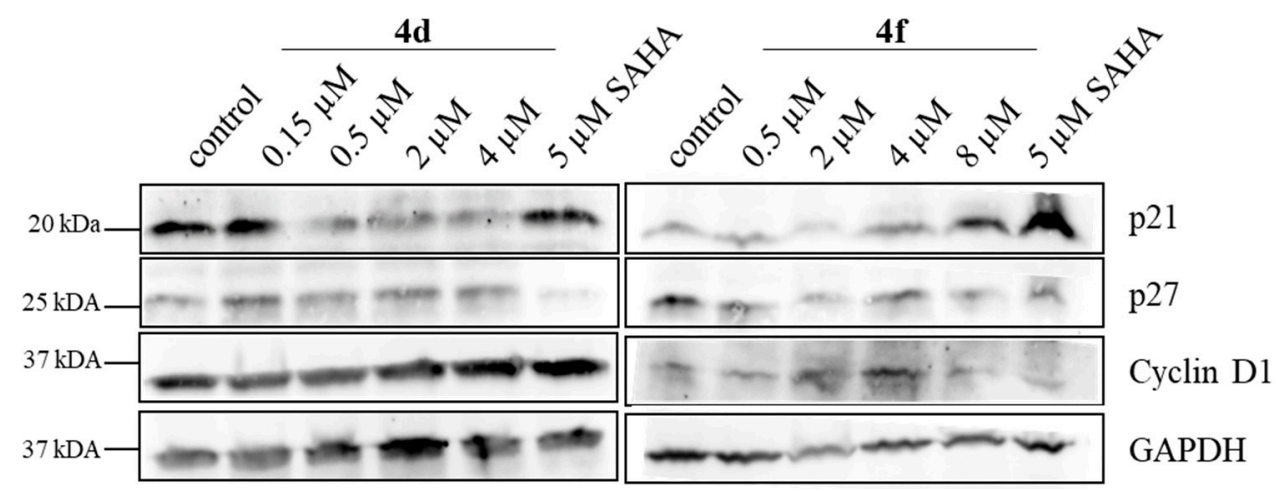

Figure 7. Compound-induced effects on cell cycle regulatory proteins in 518A2 melanoma cells after $24 \mathrm{~h}$ treatment with $\mathbf{4 d}, \mathbf{4 f}$, and SAHA. GAPDH served as a loading control. Representative data of three independent experiments are shown.

\subsection{In Silico Evaluation}

Structure-based docking was used to explore the interactions of the different compounds with the respective target proteins on a molecular level. Molecular docking is an efficient technique for calculating the binding modes of a compound and estimating their binding affinities. Docking in general is a selection and optimization process, trying to find the best fit of a molecule in the binding site of a protein according to a scoring function [46].

To evaluate the role of the varying linker-length, the CA-4 derivative (Cap) and the hydroxamic acid group (ZBG) for the binding affinity to tubulin, docking studies were performed for the structures $\mathbf{4 d}-\mathbf{f}$. In the tubulin structure $5 \mathrm{LYJ}$, used for the docking studies, the microtubule-destabilizing agent CA-4 binds to the colchicine site of the tubulin $\beta$-chain close to the interface of the neighboring tubulin $\alpha$-chain, which restrains this binding site. The CA-4 site is a buried hydrophobic pocket shaped by residues Val238, Cys241, Leu242, Leu248, Ala250, Leu255, Ala316, Ile318, Ala354, and Ile378 [47].

The docking studies for tubulin showed almost identical binding positions of the CA-4 cap of the molecules $4 \mathbf{d}-\mathbf{f}$ in the hydrophobic colchicine binding pocket similar to the original ligand CA-4 (Figure 8A). The linker extended towards the tubulin $\alpha$-chain cap and the hydroxamic acid was predicted to form hydrogen bonds with Asn349 from the $\beta$-chain $(\mathbf{4 d}-\mathbf{f})$ and potentially with Ser178 from the $\alpha$-chain (4f). As summarized in Table 4, the estimated affinities slightly decreased with increasing linker length, a finding that is in agreement with the wet-lab results. Another observation was that the longer the linker, the more twisted it needed to be to fit into the capped cavity. Thus, the chain had to adopt torsions which are only seldom observed in crystal structures and which are considered as unfavorable; see Figure 8B [48,49]. 


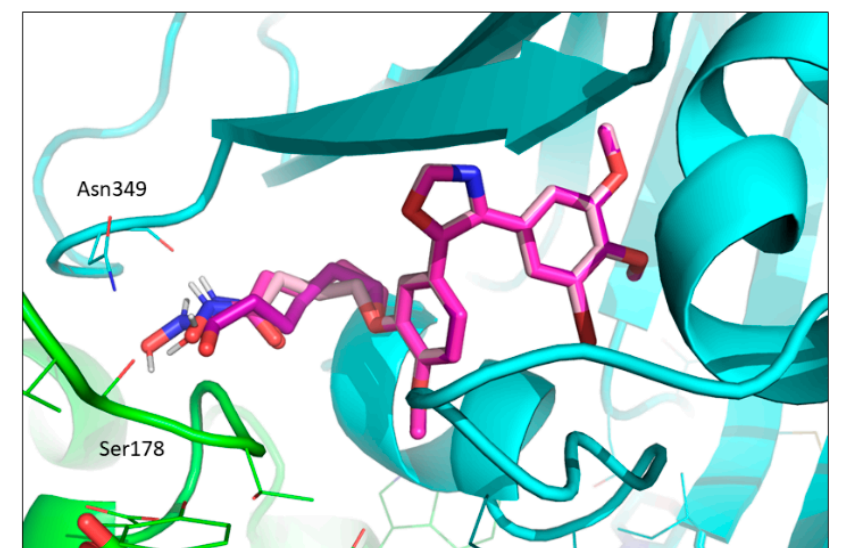

(A)

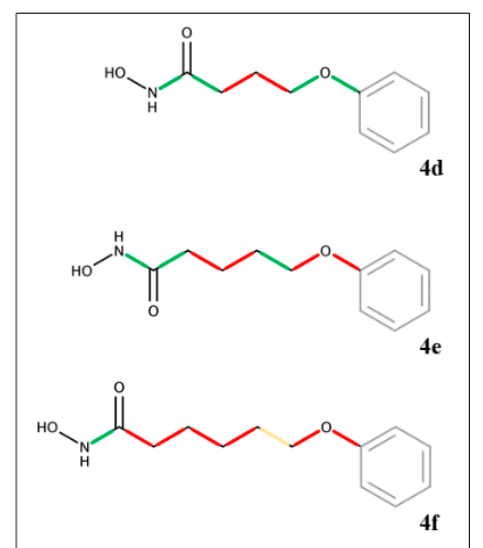

(B)

Figure 8. (A) Superposition of selected binding poses for $4 \mathrm{~d}$ (light-pink), 4e (medium-pink) and 4f (dark-pink) in tubulin structure 5LYJ, exported from SeeSAR and visualized with PyMOL. (B) Illustration of frequent (green), occasional (yellow), and rare (red) torsions within the linker and hydroxamic acid group.

Table 4. SeeSAR Docking results including estimated affinities (EA) and hydrogen bonds for Tubulin structure 5LYJ ordered by best estimated affinities.

\begin{tabular}{ccc}
\hline & EA (SeeSAR) & Hydrogen Bonds (SeeSAR) \\
\hline CA-4 & $0.11-11 \mu \mathrm{M}$ & \\
4d & $2.12-221 \mu \mathrm{M}$ & Asn349 \\
4e & $10-1019 \mu \mathrm{M}$ & Asn349 \\
4f & $24-2350 \mu \mathrm{M}$ & Asn349, Ser178 (Chain A) \\
\hline
\end{tabular}

EA ranges mark the lower and upper bound of the estimated affinities ( \pm 1.5 log-units). Note that the estimated affinity values can be quantitatively compared within one protein structure but not necessarily across different proteins.

To explore reasons for the differences in the HDAC inhibitory potency of the compounds on a molecular level, computational docking studies were performed. The calculations were based on the X-ray structures 5ICN (HDAC1) and 5EDU (HDAC6) and were carried out for the compounds $4 \mathbf{d}-\mathbf{f}$ as well as for vorinostat and the respective co-crystallized ligands (see methods section). Generally, HDACs feature an active site with a relatively narrow tunnel pointing towards the buried catalytic zinc(II) cation to which the hydroxamic acid of the natural substrates and inhibitors such as vorinostat binds. The two HDAC structures used in this study exhibit very similar binding sites and can be superimposed with a low backbone RMSD of 1.9 (superposition calculated with PyMol, see Figure 9A). 


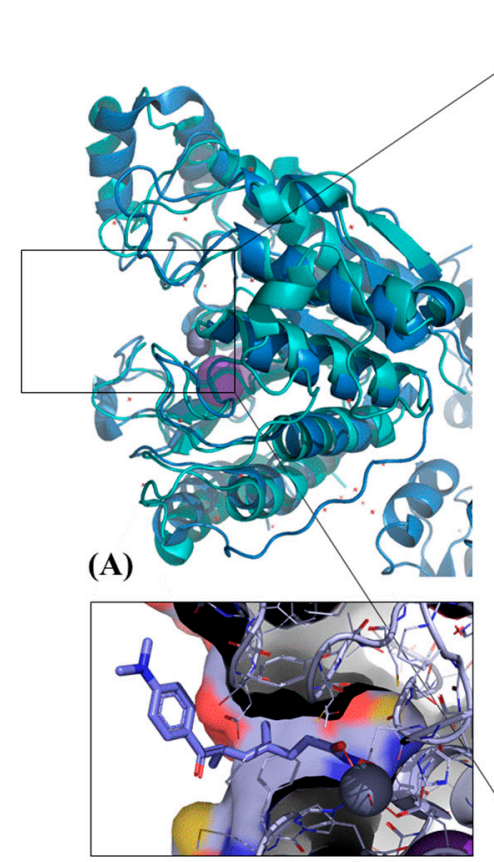

(B)
HDAC6 (5EDU)
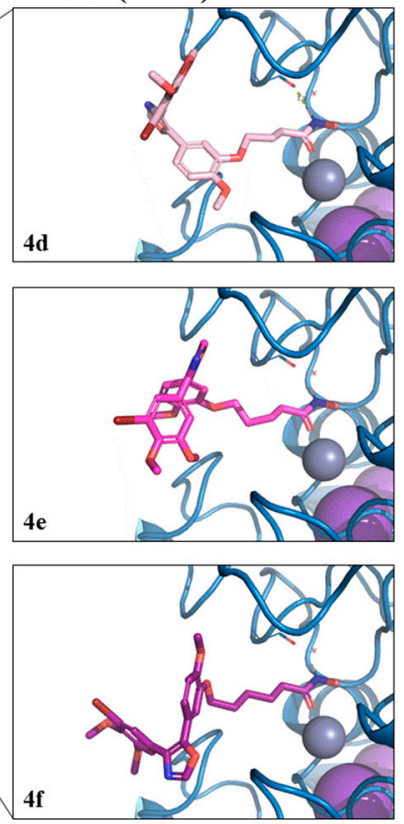

(C)
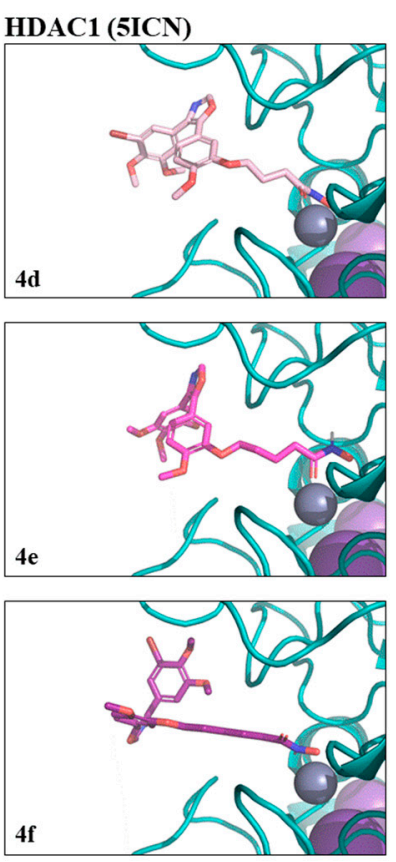

$4 \mathrm{f}$

Figure 9. (A) Aligned PDB structures of HDAC1 (PDB code: 5ICN) and HDAC6 (PDB code: 5EDU). (B) Surface visualization of HDAC6 binding site with co-crystallized ligand trichostatin A (PDB code: 5EDU). (C) Selected binding pose predictions exported from SeeSAR and visualized with PyMOL.

The best poses calculated with SeeSAR for all compounds (including re-docking of the co-crystallized ligands and vorinostat) showed a similar orientation of the linker threading through the narrow tunnel and the hydroxamic acid chelating the zinc(II) cation (Figure 9B). While the estimated affinities are all in a similar range, the values suggest that a longer linker is more favorable (Tables 5 and 6), which is in accordance with the experimental results (Table 2). This could be due to the better fit through the long (e.g., $\sim 10 \AA$ in HDAC6) and narrow active site tunnel, which would allow the hydroxamic acid group with longer linker length to reach the zinc ion more easily [50]. In contrast, the distance between the hydroxamic acid terminus and the first benzene attached to the linker in $4 \mathrm{~d}$ is only $\sim 8 \AA$, which might make it difficult to find a good hydroxamic acid fit without causing a clash of the bulky CA-4 derived capping group with the protein.

Table 5. SeeSAR docking results including estimated affinities (EA) and hydrogen bonds for HDAC6 structure 5EDU ordered by best estimated affinities.

\begin{tabular}{ccc}
\hline & EA (SeeSAR) & Hydrogen Bonds (SeeSAR) \\
\hline Trichostatin A & $<0.02 \mu \mathrm{M}$ & His610, Gly619, His611, Tyr782 \\
$\mathbf{4 f}$ & $0.32-32 \mu \mathrm{M}$ & His610, Gly619 \\
4e & $0.40-39 \mu \mathrm{M}$ & His610, Gly619 \\
Vorinostat & $1.26-125 \mu \mathrm{M}$ & His610, Gly619, His651 \\
4d & $28-2808 \mu \mathrm{M}$ & His610, Gly619, His651 \\
\hline
\end{tabular}

EA ranges mark the lower and upper bound of the estimated affinities ( \pm 1.5 log-units). Amino acids forming hydrogen bonds with hydroxamic acid are shown in bold. Note that the estimated affinity values can be quantitatively compared within one protein structure but not necessarily across different proteins.

In all docked compounds, the hydroxamic acid group formed hydrogen bonds with the buried amino acids His610 and Gly619 of the HDAC6 structure 5EDU (co-crystallized to trichostatin A) as well as a bond to the zinc ion [50]. Generally, the hydroxamic acid and the more buried part of the linker of all three compounds $4 \mathbf{d}-\mathbf{f}$ overlap also with the respective part of the co-crystallized trichostatin $\mathrm{A}$ (Figure 9C, left panel). The capping group, which is rather solvent exposed, was more variable in its position, but may form hydrogen bonds with His651 and Phe680. 
The docking results for HDAC1 structure $5 \mathrm{ICN}$ were more diverse. This could be due to the fact that the structure is co-crystallized with a peptide inhibitor $(\mathrm{H} 4 \mathrm{~K} 16 \mathrm{Hx})$ and the loop around residue Asp99 undergoes a significant rearrangement to allow binding of the peptide [51]. Note that there are only two HDAC1 structures available to date (5ICN and 4BKX), of which 4BKX is an apo structure, so $5 \mathrm{ICN}$ was the only available complex structure. Reasonable poses for all compounds could be generated with LeadIT, whereas the optimization in SeeSAR was successful for all compounds but $4 \mathrm{~d}$ (Figure 9C, right panel). Furthermore, the binding poses of the three compounds $4 \mathbf{d}-\mathbf{f}$ and vorinostat differed more in the hydrogen and metal bonds formed by the hydroxamic acid. While the hydroxamic acid group of $\mathbf{4 f}$ was predicted to form hydrogen bonds with Tyr303 and His141, it was predicted to only form one hydrogen bond with Gly301 in 4e. The capping group might form H-Bonds with Asn95 and Gly149.

Table 6. SeeSAR docking results including estimated affinities (EA) and hydrogen bonds for HDAC1 structure 5 ICN ordered by best estimated affinities.

\begin{tabular}{ccc}
\hline & EA (SeeSAR) & Hydrogen Bonds (SeeSAR) \\
\hline H4K16Hx & $<0.81 \mu \mathrm{M}$ & Tyr303, His140, His141, Asn95, Glu98, Asp99, Cys100, Gly149 \\
4f & $56-5.543 \mu \mathrm{M}$ & Tyr303, His141, Asn95, Gly149 \\
Vorinostat & $1.049-104.186 \mu \mathrm{M}$ & His140, Gly149 \\
4e & $3.814-378.935 \mu \mathrm{M}$ & Gly301, Asn95 \\
4d & Not scored & - \\
\hline
\end{tabular}

EA ranges mark the lower and upper bound of the estimated affinities ( \pm 1.5 log-units). Amino acids forming hydrogen bonds with hydroxamic acid are shown in bold. Note that the estimated affinity values can be quantitatively compared within one protein structure but not necessarily across different proteins.

While the results were more distinct for HDAC6 (where a good protein-ligand complex structure was available), generally, the docking analysis showed that the molecules with longer linker length tend to have a higher affinity to HDAC1 and HDAC6.

\section{Discussion}

Recently, we presented conjugates of imidazoles and hydroxamic acids which combine HDAC inhibition with cytoskeletal modulation [34,38,52]. However, conjugates with imidazoles derived from CA-4 had lost crucial CA-4 typical properties such as inhibition of the polymerization of tubulin. Herein, we introduced a new series of conjugates of oxazole-bridged CA-4 and hydroxamic acids that show dual tubulin and HDAC interference which mainly depends on the length of the linker connecting these two fragments. In terms of cytotoxicity, inhibition of tubulin polymerization, and generation of ROS, the potency of these conjugates grows with decreasing linker length. The strong anti-proliferative effect especially of the derivatives with the shortest linkers $4 \mathbf{a}, 4 \mathrm{~d}$, and $\mathbf{4 g}$ is probably due to their interference with formation of the spindle apparatus during mitosis. The derivatives with longer tethers increasingly lose this property resulting in a distinctly reduced anti-proliferative effect which was confirmed by in silico studies and was attributed to the increasingly tensed fitting of the linkers in the capped cavity.

By destabilizing the microtubules, the new conjugates affect the cell division and probably the integrity of endothelial cell layers. Moreover, they showed a distinct specificity for endothelial hybrid cells Ea.Hy926 over non-malignant cells HDFa. Both properties underline the great potential of these derivatives as VDAs which trigger the collapse of the leaky and low-quality blood vessels of tumors by destabilizing their endothelial lining, initiating necrosis in the core of the tumor [19]. An assessment of the vascular-disrupting activity of the new compounds is currently underway.

The HDAC inhibitory effect of the new conjugates showed the opposite dependency on linker length. The $\mathrm{IC}_{50}$ values for inhibition of both HDAC1 and HDAC6 decreased with increasing linker length reflecting the fact that the active site of the zinc-dependent HDACs is accessible for HDACi only by a long narrow hydrophobic channel. We rationalized this trend by in silico experiments. 
The observed G1-arrest of 518A2 cells by $\mathbf{4 f}$ matches with similar observations for other HDACi. The MDA-typical G2/M arrest by derivatives $4 \mathbf{d}$ and $4 \mathbf{e}$ is in line with their pronounced microtubule disrupting effect which probably overrides their HDACi activity. The stress fiber induction as well as the anti-migratory activity observed for $\mathbf{4} \mathbf{d}-\mathbf{f}$ was independent of linker length. Together with the lack of toxicity in mice, compound $\mathbf{4 d}$ appears to be an especially promising drug candidate.

In this work we were able to demonstrate the anti-proliferative, cell-cycle arresting, microtubule-destabilizing and actin stress fiber-inducing effects of novel CA-4 analogues with the potential to inhibit histone deacetylases. The results are indicative of the great potential of this new class of compounds which probably affect the tumor vasculature either by inhibiting angiogenesis or by disruption of already established tumor blood vessels. Investigations of these anti-vascular effects as well as their in vivo activity are currently underway.

\section{Materials and Methods}

\subsection{General Procedures}

The following instruments were used: melting points (uncorrected), Gallenkamp; IR spectra, Perkin-Elmer Spectrum One FT-IR spectrophotometer with ATR sampling unit; nuclear magnetic resonance spectra, BRUKER Avance 300 spectrometer; chemical shifts are given in parts per million ( $)$ downfield from tetramethylsilane as internal standard; mass spectra, Varian MAT 311A (EI) or UPLC/Orbitrap MS system (ESI); microanalyses, Perkin-Elmer 2400 CHN elemental analyzer. All tested compounds were $>95 \%$ pure by elemental analysis.

\subsection{Materials}

The known starting compounds $\mathbf{1 a}$ and $\mathbf{2 a - c}$ were prepared according to literature procedures [25-27]. The new compounds $\mathbf{1} \mathbf{b}$ and $\mathbf{1 c}$ were synthesized analogously to $\mathbf{1 a}$ (see below). All other starting compounds and reagents were purchased from Sigma-Aldrich.

\subsection{General Procedure for the Synthesis of Intermediates $1 b$ and $1 c$}

Isovanillin (152 mg, $1.0 \mathrm{mmol}$ ) was dissolved in MeCN (5 mL) and cesium carbonate (652 mg, $2.0 \mathrm{mmol})$ was added. After stirring at $90^{\circ} \mathrm{C}$ for $0.5 \mathrm{~h}$, ethyl 5-bromovalerate $(328 \mu \mathrm{L}, 2.0 \mathrm{mmol})$ or ethyl 6-bromohexanoate $(356 \mu \mathrm{L}, 2.0 \mathrm{mmol})$, respectively, was added and the reaction mixture was stirred at $90^{\circ} \mathrm{C}$ for $2 \mathrm{~h}$. After filtration through celite, the solvent was removed under reduced pressure and the residue was washed twice with $n$-hexane. The resulting oil was dried in vacuum and used for the next step without further purification.

Ethyl 5-(1-methoxy-4-formyl-2-phenoxy)valerate (1b). Yield: $130 \mathrm{mg}(0.46 \mathrm{mmol}, 46 \%)$; colorless oil. $v_{\max }(\mathrm{ATR}) / \mathrm{cm}^{-1} 2941,2881,2841,1728,1683,1585,1509,1462,1436,1393,1374,1340,1262,1238$, $1159,1133,1096,1019,935,864,809,780,749,737,641 .{ }^{1} \mathrm{H} \mathrm{NMR}\left(300 \mathrm{MHz}, \mathrm{CDCl}_{3}\right): \delta=1.23(\mathrm{t}, 3 \mathrm{H}, J=$ $7.1 \mathrm{~Hz}), 1.8-2.0(\mathrm{~m}, 4 \mathrm{H}), 2.38(\mathrm{t}, 2 \mathrm{H}, J=7.3 \mathrm{~Hz}), 3.93(\mathrm{~s}, 3 \mathrm{H}), 4.0-4.2(\mathrm{~m}, 4 \mathrm{H}), 6.95(\mathrm{~d}, 1 \mathrm{H}, J=8.2 \mathrm{~Hz})$, $7.37(\mathrm{~s}, 1 \mathrm{H}), 7.44(\mathrm{~d}, 2 \mathrm{H}, J=8.2 \mathrm{~Hz}), 9.82 \mathrm{ppm}(\mathrm{s}, 1 \mathrm{H}) .{ }^{13} \mathrm{C} \mathrm{NMR}\left(75.5 \mathrm{MHz}, \mathrm{CDCl}_{3}\right): \delta=14.2,21.6,28.5$, $33.9,56.2,60.3,68.5,110.5,110.7,126.7,130.1,149.0,154.9,173.3,190.9$ ppm. $\mathrm{m} / z$ (\%) 280 (14) $\left[\mathrm{M}^{+}\right], 235$ (24), 151 (57), 129 (98), 101 (100), 83 (82), 55 (56), 43 (15).

Ethyl 6-(1-methoxy-4-formyl-2-phenoxy)hexanoate (1c). Yield: $110 \mathrm{mg}(0.37 \mathrm{mmol}, 37 \%)$; colorless oil. $v_{\max }(\mathrm{ATR}) / \mathrm{cm}^{-1}$ 2940, 2870, 1729, 1685, 1585, 1510, 1462, 1436, 1394, 1374, 1341, 1264, $1239,1161,1134,1068,1021,862,811,779,749,729,641 .{ }^{1} \mathrm{H}$ NMR $\left(300 \mathrm{MHz}, \mathrm{CDCl}_{3}\right): \delta=1.23(\mathrm{t}, 3 \mathrm{H}, J=$ $7.1 \mathrm{~Hz}), 1.4-1.6(\mathrm{~m}, 2 \mathrm{H}), 1.6-1.8(\mathrm{~m}, 2 \mathrm{H}), 1.8-1.9(\mathrm{~m}, 2 \mathrm{H}), 2.32(\mathrm{t}, 2 \mathrm{H}, J=7.3 \mathrm{~Hz}), 4.01(\mathrm{~s}, 3 \mathrm{H}), 4.0-4.2(\mathrm{~m}$, $4 \mathrm{H}), 6.95(\mathrm{~d}, 1 \mathrm{H}, J=8.2 \mathrm{~Hz}), 7.37(\mathrm{~s}, 1 \mathrm{H}), 7.44(\mathrm{~d}, 2 \mathrm{H}, J=8.2 \mathrm{~Hz}), 9.82 \mathrm{ppm}(\mathrm{s}, 1 \mathrm{H}) .{ }^{13} \mathrm{C} \mathrm{NMR}(75.5 \mathrm{MHz}$, $\left.\mathrm{CDCl}_{3}\right): \delta=14.2,24.7,25.6,28.7,34.2,56.2,60.2,68.8,110.4,110.6,118.0,126.6,130.1,149.1,154.9,173.6$, 190.9 ppm. m/z (\%) 294 (48) [M+ $], 249$ (35), 152 (98), 143 (100), 115 (54), 97 (97), 69 (86), 55 (22), 41 (28). 


\subsection{General Procedure for the Synthesis of Intermediates $3 \boldsymbol{a}-\boldsymbol{i}$}

The respective compounds $1(0.42 \mathrm{mmol})$ and $2(0.42 \mathrm{mmol})$ and $\mathrm{K}_{2} \mathrm{CO}_{3}(590 \mathrm{mg}, 4.3 \mathrm{mmol})$ were suspended in ethanol and stirred under reflux for $2 \mathrm{~h}$. The solvent was removed and the residue dissolved in ethyl acetate and washed with water. The organic phase was dried over $\mathrm{Na}_{2} \mathrm{SO}_{4}$, concentrated in vacuum, and the residue was purified by column chromatography (silica gel 60).

Ethyl 4-[1-methoxy-4-(4'-(3"-chloro-4",5"-dimethoxyphenyl)oxazol-5'-yl)-2-phenoxy] butyrate (3a). Compound 3a was obtained from 1a (113 mg, $0.42 \mathrm{mmol}), 2 \mathrm{a}(155 \mathrm{mg}, 0.42 \mathrm{mmol})$ and $\mathrm{K}_{2} \mathrm{CO}_{3}$ (590 mg, $4.3 \mathrm{mmol}$ ). Yield: $103 \mathrm{mg}(0.22 \mathrm{mmol}, 52 \%) ; \mathrm{R} f=0.39$ (ethyl acetate $/ n$-hexane, $2: 3$ ); colorless oil. $v_{\max }$ (ATR) $/ \mathrm{cm}^{-1}$ 2969, 2938, 2876, 2837, 1731, 1683, 1629, 1561, 1513, 1489, 1463, 1443, 1414, 1399, 1366, 1303, 1254, 1229, 1174, 1140, 1117, 1105, 1047, 1024, 1000, 960, 938, 892, 853, 810, 774, 758, 734, 709, 659, 629. ${ }^{1} \mathrm{H}$ NMR $\left(300 \mathrm{MHz}, \mathrm{CDCl}_{3}\right): \delta=1.23(\mathrm{t}, 3 \mathrm{H}, J=7.1 \mathrm{~Hz}), 2.0-2.2(\mathrm{~m}, 2 \mathrm{H}), 2.49(\mathrm{t}, 2 \mathrm{H}, J=$ $7.3 \mathrm{~Hz}), 3.81(\mathrm{~s}, 3 \mathrm{H}), 3.87(\mathrm{~s}, 3 \mathrm{H}), 3.88(\mathrm{~s}, 3 \mathrm{H}), 3.98(\mathrm{t}, 2 \mathrm{H}, J=6.3 \mathrm{~Hz}), 4.11(\mathrm{q}, 2 \mathrm{H}, J=7.2 \mathrm{~Hz}), 6.87(\mathrm{~d}, 1 \mathrm{H}$, $J=8.4 \mathrm{~Hz}), 7.1-7.2(\mathrm{~m}, 3 \mathrm{H}), 7.29(\mathrm{~s}, 1 \mathrm{H}), 7.88 \mathrm{ppm}(\mathrm{s}, 1 \mathrm{H}) .{ }^{13} \mathrm{C} \mathrm{NMR}\left(75.5 \mathrm{MHz}, \mathrm{CDCl}_{3}\right): \delta=14.2,24.5$, 30.7, 56.0, 56.1, 60.4, 60.8, 68.1, 110.6, 111.7, 112.0, 120.4, 120.9, 121.1, 128.3, 128.7, 132.3, 146.1, 148.4,

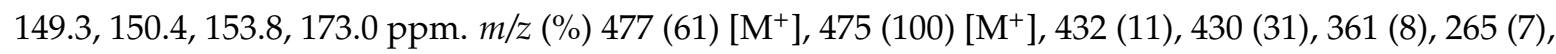
115 (94), 87 (67), 43 (11).

Ethyl 5-[1-methoxy-4-(4'-(3"-chloro-4",5"-dimethoxyphenyl)oxazol-5'-yl)-2-phenoxy]valerate (3b). Compound $\mathbf{3 b}$ was obtained from $\mathbf{1 b}(126 \mathrm{mg}, 0.45 \mathrm{mmol}), \mathbf{2 a}(165 \mathrm{mg}, 0.45 \mathrm{mmol})$ and $\mathrm{K}_{2} \mathrm{CO}_{3}$ (590 mg, $4.3 \mathrm{mmol})$. Yield: $98 \mathrm{mg}(0.20 \mathrm{mmol}, 44 \%) ; \mathrm{R} f=0.42$ (ethyl acetate $/ n$-hexane, $2: 3)$; colorless oil. $v_{\max }($ ATR $) / \mathrm{cm}^{-1} 2938,2870,2838,1730,1603,1591,1564,1513,1489,1463,1414,1365,1324,1294$, 1254, 1229, 1203, 1164, 1140, 1105, 1048, 1024, 938, 854, 811, 776, 758, 710, 659, 628. ${ }^{1} \mathrm{H}$ NMR (300 MHz, $\left.\mathrm{CDCl}_{3}\right): \delta=1.23(\mathrm{t}, 3 \mathrm{H}, J=7.1 \mathrm{~Hz}), 1.7-1.9(\mathrm{~m}, 2 \mathrm{H}), 2.35(\mathrm{t}, 2 \mathrm{H}, J=7.3 \mathrm{~Hz}), 3.81(\mathrm{~s}, 3 \mathrm{H}), 3.87(\mathrm{~s}, 3 \mathrm{H}), 3.88$ $(\mathrm{s}, 3 \mathrm{H}), 3.93(\mathrm{t}, 2 \mathrm{H}, J=6.1 \mathrm{~Hz}), 4.10(\mathrm{q}, 2 \mathrm{H}, J=7.1 \mathrm{~Hz}), 6.87(\mathrm{~d}, 1 \mathrm{H}, J=8.4 \mathrm{~Hz}), 7.10(\mathrm{~s}, 1 \mathrm{H}), 7.1-7.2(\mathrm{~m}$, 2H), 7.30 (s, 1H), $7.88 \mathrm{ppm}(\mathrm{s}, 1 \mathrm{H}) .{ }^{13} \mathrm{C} \mathrm{NMR}\left(75.5 \mathrm{MHz}, \mathrm{CDCl}_{3}\right): \delta=14.2,21.6,28.6,33.9,56.0,56.1$, $60.3,60.8,68.7,110.6,111.7,120.2,120.9,121.1,128.3,128.7,132.3,145.2,146.1,148.5,149.3,150.3,153.8$,

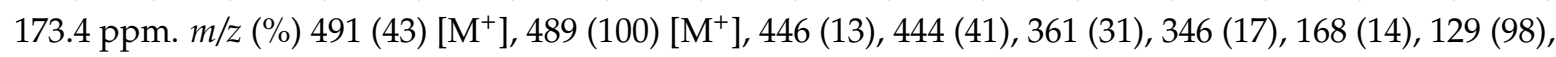
101 (98), 83 (56), 55 (39), 43 (11).

Ethyl 6-[1-methoxy-4-(4'-(3"-chloro-4",5"-dimethoxyphenyl)oxazol-5'-yl)-2-phenoxy] hexanoate (3c). Compound 3c was obtained from $1 \mathrm{c}(91 \mathrm{mg}, 0.31 \mathrm{mmol}), 2 \mathrm{a}(113 \mathrm{mg}, 0.31 \mathrm{mmol})$ and $\mathrm{K}_{2} \mathrm{CO}_{3}$ (590 mg, $4.3 \mathrm{mmol})$. Yield: $63 \mathrm{mg}(0.13 \mathrm{mmol}, 42 \%) ; \mathrm{R} f=0.45$ (ethyl acetate $/ n$-hexane, $2: 3$ ); colorless oil. $v_{\max }($ ATR $) / \mathrm{cm}^{-1} 2939,2871,2837,1730,1605,1591,1563,1513,1489,1463,1414,1366,1325,1300$, $1255,1229,1203,1175,1165,1140,1105,1048,1024,1001,939,854,821,775,758,710,659,629 .{ }^{1} \mathrm{H}$ NMR $\left(300 \mathrm{MHz}, \mathrm{CDCl}_{3}\right): \delta=1.23(\mathrm{t}, 3 \mathrm{H}, J=7.1 \mathrm{~Hz}), 1.4-1.5(\mathrm{~m}, 2 \mathrm{H}), 1.6-1.7(\mathrm{~m}, 2 \mathrm{H}), 1.8-1.9(\mathrm{~m}, 2 \mathrm{H}), 2.30(\mathrm{t}$, $2 \mathrm{H}, J=7.3 \mathrm{~Hz}), 3.80(\mathrm{~s}, 3 \mathrm{H}), 3.87(\mathrm{~s}, 3 \mathrm{H}), 3.88(\mathrm{~s}, 3 \mathrm{H}), 3.92(\mathrm{t}, 2 \mathrm{H}, J=6.7 \mathrm{~Hz}), 4.10(\mathrm{q}, 2 \mathrm{H}, J=7.1 \mathrm{~Hz})$, $6.88(\mathrm{~d}, 1 \mathrm{H}, J=8.4 \mathrm{~Hz}), 7.10(\mathrm{~s}, 1 \mathrm{H}), 7.1-7.2(\mathrm{~m}, 2 \mathrm{H}), 7.30(\mathrm{~s}, 1 \mathrm{H}), 7.89 \mathrm{ppm}(\mathrm{s}, 1 \mathrm{H}) .{ }^{13} \mathrm{C} \mathrm{NMR}(75.5 \mathrm{MHz}$, $\left.\mathrm{CDCl}_{3}\right): \delta=14.2,24.7,25.6,28.8,34.2,56.0,56.1,60.2,60.8,68.9,110.6,111.6,120.1,120.9,121.1,128.3$, $128.7,132.3,145.2,146.1,148.6,149.3,150.3,153.8,173.6 \mathrm{ppm} . \mathrm{m} / \mathrm{z}(\%) 505(68)\left[\mathrm{M}^{+}\right], 503(100)\left[\mathrm{M}^{+}\right], 458$ (11), 361 (37), 346 (13), 143 (51), 115 (16), 97 (28), 69 (26).

Ethyl 4-[1-methoxy-4-(4'-(3"-bromo-4", $5^{\prime \prime}$-dimethoxyphenyl)oxazol-5'-yl)-2-phenoxy] butyrate (3d). Compound 3d was obtained from $\mathbf{1 a}(125 \mathrm{mg}, 0.47 \mathrm{mmol}), \mathbf{2 b}(192 \mathrm{mg}, 0.47 \mathrm{mmol})$ and $\mathrm{K}_{2} \mathrm{CO}_{3}$ (590 mg, $4.3 \mathrm{mmol})$. Yield: $100 \mathrm{mg}(0.19 \mathrm{mmol}, 41 \%) ; \mathrm{R} f=0.25$ (ethyl acetate $/ n$-hexane, $1: 2)$; colorless oil. $v_{\max }$ (ATR)/ $\mathrm{cm}^{-1} 3118,2986,2940,2837,1739,1592,1561,1514,1488,1468,1441,1404,1388,1362$, 1349, 1267, 1256, 1241, 1226, 1208, 1179, 1145, 1124, 1108, 1072, 1048, 1025, 997, 960, 944, 859, 846, 820, 807, 773, 754, 699, 654. ${ }^{1} \mathrm{H}$ NMR $\left(300 \mathrm{MHz}, \mathrm{CDCl}_{3}\right): \delta=1.23(\mathrm{t}, 3 \mathrm{H}, J=7.2 \mathrm{~Hz}), 2.0-2.2(\mathrm{~m}, 2 \mathrm{H}), 2.50(\mathrm{t}$, $2 \mathrm{H}, J=7.3 \mathrm{~Hz}), 3.80(\mathrm{~s}, 3 \mathrm{H}), 3.86(\mathrm{~s}, 3 \mathrm{H}), 3.88(\mathrm{~s}, 3 \mathrm{H}), 3.98(\mathrm{t}, 2 \mathrm{H}, J=6.3 \mathrm{~Hz}), 4.11(\mathrm{q}, 2 \mathrm{H}, J=7.2 \mathrm{~Hz})$, $6.88(\mathrm{~d}, 1 \mathrm{H}, J=8.4 \mathrm{~Hz}), 7.12(\mathrm{~s}, 1 \mathrm{H}), 7.1-7.2(\mathrm{~m}, 2 \mathrm{H}), 7.46(\mathrm{~s}, 1 \mathrm{H}), 7.88 \mathrm{ppm}(\mathrm{s}, 1 \mathrm{H}) .{ }^{13} \mathrm{C}$ NMR $(75.5 \mathrm{MHz}$, $\left.\mathrm{CDCl}_{3}\right): \delta=14.2,24.5,30.8,56.0,56.1,60.4,60.7,68.2,111.4,111.7,111.9,117.6,120.3,120.9,123.9,129.3$, 146.1, 148.4, 149.3, 150.4, 153.7, 173.0 ppm. $\mathrm{m} / \mathrm{z}(\%) 521(38)\left[\mathrm{M}^{+}\right], 519(37)\left[\mathrm{M}^{+}\right], 476(6), 474(5), 115$ (100), 87 (79), 43 (14). 
Ethyl 5-[1-methoxy-4-(4'-(3"'-bromo-4",5"-dimethoxyphenyl)oxazol-5'-yl)-2-phenoxy]valerate (3e). Compound $3 \mathbf{e}$ was obtained from $\mathbf{1 b}(112 \mathrm{mg}, 0.40 \mathrm{mmol})$ and $\mathbf{2 b}(164 \mathrm{mg}, 0.40 \mathrm{mmol})$ and $\mathrm{K}_{2} \mathrm{CO}_{3}(590 \mathrm{mg}, 4.3 \mathrm{mmol})$. Yield: $110 \mathrm{mg}(0.21 \mathrm{mmol}, 53 \%) ; \mathrm{R} f=0.33$ (ethyl acetate $/ n$-hexane, $\left.2: 3\right)$; colorless oil. $v_{\max }($ ATR $) / \mathrm{cm}^{-1} 3128,2938,2838,1730,1591,1557,1513,1485,1463,1414,1364,1254$, 1230, 1201, 1174, 1162, 1140, 1105, 1043, 1025, 1000, 939, 897, 854, 807, 776, 754, 698, 659, 628. ${ }^{1} \mathrm{H}$ NMR $\left(300 \mathrm{MHz}, \mathrm{CDCl}_{3}\right): \delta=1.23(\mathrm{t}, 3 \mathrm{H}, J=7.1 \mathrm{~Hz}), 1.7-1.9(\mathrm{~m}, 4 \mathrm{H}), 2.36(\mathrm{t}, 2 \mathrm{H}, J=7.3 \mathrm{~Hz}), 3.80(\mathrm{~s}, 3 \mathrm{H}), 3.86$ $(\mathrm{s}, 3 \mathrm{H}), 3.88(\mathrm{~s}, 3 \mathrm{H}), 3.93(\mathrm{t}, 2 \mathrm{H}, J=6.1 \mathrm{~Hz}), 4.10(\mathrm{q}, 2 \mathrm{H}, J=7.1 \mathrm{~Hz}), 6.88(\mathrm{~d}, 1 \mathrm{H}, J=8.4 \mathrm{~Hz}), 7.11(\mathrm{~s}, 1 \mathrm{H})$, 7.1-7.2 (m, 2H), $7.47(\mathrm{~s}, 1 \mathrm{H}), 7.88 \mathrm{ppm}(\mathrm{s}, 1 \mathrm{H}) .{ }^{13} \mathrm{C}$ NMR $\left(75.5 \mathrm{MHz}, \mathrm{CDCl}_{3}\right): \delta=14.2,21.6,28.6,33.9$, 56.0, 56.1, 60.3, 60.7, 68.7, 111.4, 111.6, 111.7, 117.6, 120.1, 120.9, 123.9, 129.4, 132.1, 146.1, 146.3, 148.6,

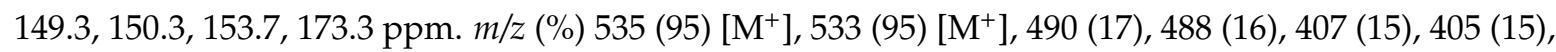
129 (96), 101 (100), 83 (42), 55 (40).

Ethyl 6-[1-methoxy-4-(4'-(3"-bromo-4",5"-dimethoxyphenyl)oxazol-5'-yl)-2-phenoxy] hexanoate (3f). Compound 3f was obtained from $1 \mathbf{c}(113 \mathrm{mg}, 0.38 \mathrm{mmol}), 2 \mathbf{b}(158 \mathrm{mg}, 0.38 \mathrm{mmol})$ and $\mathrm{K}_{2} \mathrm{CO}_{3}$ (590 mg, $4.3 \mathrm{mmol}$ ). Yield: $80 \mathrm{mg}(0.15 \mathrm{mmol}, 40 \%) ; \mathrm{R} f=0.45$ (ethyl acetate $/ n$-hexane, $2: 3$ ); colorless oil. $v_{\max }($ ATR $) / \mathrm{cm}^{-1}$ 2940, 2869, 1730, 1590, 1558, 1513, 1485, 1463, 1414, 1364, 1323, 1253, 1229, 1175, 1160, 1140, 1105, 1066, 1043, 1025, 999, 938, 853, 806, 775, 753, 697, 659, 628. ${ }^{1} \mathrm{H}$ NMR $\left(300 \mathrm{MHz}, \mathrm{CDCl}_{3}\right): \delta=$ $1.23(\mathrm{t}, 3 \mathrm{H}, J=7.1 \mathrm{~Hz}), 1.4-1.5(\mathrm{~m}, 2 \mathrm{H}), 1.6-1.8(\mathrm{~m}, 2 \mathrm{H}), 1.8-1.9(\mathrm{~m}, 2 \mathrm{H}), 2.30(\mathrm{t}, 2 \mathrm{H}, J=7.3 \mathrm{~Hz}), 3.80(\mathrm{~s}$, $3 \mathrm{H}), 3.86(\mathrm{~s}, 3 \mathrm{H}), 3.88(\mathrm{~s}, 3 \mathrm{H}), 3.9-4.0(\mathrm{~m}, 5 \mathrm{H}), 4.10(\mathrm{q}, 2 \mathrm{H}, J=7.1 \mathrm{~Hz}), 6.88(\mathrm{~d}, 1 \mathrm{H}, J=8.4 \mathrm{~Hz}), 7.10(\mathrm{~s}$, $1 \mathrm{H}), 7.1-7.2(\mathrm{~m}, 2 \mathrm{H}), 7.47(\mathrm{~s}, 1 \mathrm{H}), 7.88 \mathrm{ppm}(\mathrm{s}, 1 \mathrm{H}) .{ }^{13} \mathrm{C} \mathrm{NMR}\left(75.5 \mathrm{MHz}, \mathrm{CDCl}_{3}\right): \delta=14.2,24.7,25.6$, $28.8,34.2,56.0,56.1,60.2,60.7,68.9,111.4,111.6,111.7,117.6,120.0,120.9,123.9,129.4,132.1,146.2$, 148.6, 149.3, 150.3, 153.7, 173.6 ppm. $m / z(\%) 549(99)\left[\mathrm{M}^{+}\right], 547(100)\left[\mathrm{M}^{+}\right], 407$ (31), 405 (32), 143 (77), 115 (20), 97 (32), 69 (27).

Ethyl 4-[1-methoxy-4-(4'-(3",4",5"-trimethoxyphenyl)oxazol-5'-yl)-2-phenoxy]butyrate (3g). Compound $3 \mathrm{~g}$ was obtained from $1 \mathrm{a}(134 \mathrm{mg}, 0.50 \mathrm{mmol}), 2 \mathrm{c}(182 \mathrm{mg}, 0.50 \mathrm{mmol})$ and $\mathrm{K}_{2} \mathrm{CO}_{3}(590 \mathrm{mg}$, $4.3 \mathrm{mmol}$ ). Yield: $124 \mathrm{mg}(0.26 \mathrm{mmol}, 52 \%) ; \mathrm{R} f=0.31$ (ethyl acetate $/ n$-hexane, $1: 1)$; colorless oil. $v_{\max }($ ATR $) / \mathrm{cm}^{-1} 2939,2840,1730,1583,1515,1463,1415,1372,1306,1255,1236,1173,1122,1022,1004$, 956, 938, 885, 837, 811, 768, 733, 659, 629. ${ }^{1} \mathrm{H}$ NMR $\left(300 \mathrm{MHz}, \mathrm{CDCl}_{3}\right): \delta=1.27(\mathrm{t}, 3 \mathrm{H}, J=7.1 \mathrm{~Hz})$, 2.1-2.2 (m, 2H), $2.53(\mathrm{t}, 2 \mathrm{H}, J=7.3 \mathrm{~Hz}), 3.81(\mathrm{~s}, 6 \mathrm{H}), 3.90(\mathrm{~s}, 3 \mathrm{H}), 3.91(\mathrm{~s}, 3 \mathrm{H}), 4.02(\mathrm{t}, 2 \mathrm{H}, J=6.3 \mathrm{~Hz}), 4.15$ $(\mathrm{q}, 2 \mathrm{H}, J=7.1 \mathrm{~Hz}), 6.90(\mathrm{~d}, 1 \mathrm{H}, J=8.4 \mathrm{~Hz}), 7.12(\mathrm{~s}, 1 \mathrm{H}), 6.94(\mathrm{~s}, 2 \mathrm{H}), 7.17(\mathrm{~s}, 1 \mathrm{H}), 7.25(\mathrm{~d}, 1 \mathrm{H}, J=8.4 \mathrm{~Hz})$, $7.93 \mathrm{ppm}(\mathrm{s}, 1 \mathrm{H}) .{ }^{13} \mathrm{C}$ NMR $\left(75.5 \mathrm{MHz}, \mathrm{CDCl}_{3}\right): \delta=14.2,24.5,30.7,56.0,56.1,60.4,60.9,68.0,104.9$, 111.5, 112.1, 120.4, 121.3, 127.6, 133.6, 137.9, 145.6, 148.3, 149.2, 150.1, 153.3, 173.0 ppm. $\mathrm{m} / \mathrm{z}$ (\%) 471 (95) $\left[\mathrm{M}^{+}\right], 456$ (13), 426 (31), 195 (17), 115 (100), 87 (99), 69 (14), 43 (24). Elemental analysis calculated (\%) for $\mathrm{C}_{25} \mathrm{H}_{29} \mathrm{NO}_{8}: \mathrm{C} 63.68, \mathrm{H}$ 6.20, N 2.97. Found: C 63.65, H 6.18, N 2.96.

Ethyl 5-[1-methoxy-4-(4'-(3",4", 5"-trimethoxyphenyl)oxazol-5'-yl)-2-phenoxy]valerate (3h). Compound $3 \mathrm{~h}$ was obtained from $\mathbf{1 b}(130 \mathrm{mg}, 0.46 \mathrm{mmol}), 2 \mathrm{c}(168 \mathrm{mg}, 0.46 \mathrm{mmol})$ and $\mathrm{K}_{2} \mathrm{CO}_{3}(590 \mathrm{mg}$, $4.3 \mathrm{mmol}$ ). Yield: $107 \mathrm{mg}(0.22 \mathrm{mmol}, 48 \%) ; \mathrm{R} f=0.35$ (ethyl acetate $/ n$-hexane, $1: 1$ ); colorless oil. $v_{\max }($ ATR $) / \mathrm{cm}^{-1} 2938,2840,1730,1583,1515,1455,1415,1372,1330,1305,1255,1237,1171,1123,1022$, $1004,938,894,837,811,768,734,659,629 .{ }^{1} \mathrm{H} \mathrm{NMR}\left(300 \mathrm{MHz}, \mathrm{CDCl}_{3}\right): \delta=1.23(\mathrm{t}, 3 \mathrm{H}, J=7.1 \mathrm{~Hz})$, 1.7-1.9 (m, 4H), $2.34(\mathrm{~d}, 2 \mathrm{H}, J=7.2 \mathrm{~Hz}), 3.77(\mathrm{~s}, 6 \mathrm{H}), 3.85(\mathrm{~s}, 3 \mathrm{H}), 3.87(\mathrm{~s}, 3 \mathrm{H}), 3.93(\mathrm{t}, 2 \mathrm{H}, J=6.1 \mathrm{~Hz})$, $4.10(\mathrm{q}, 2 \mathrm{H}, J=7.1 \mathrm{~Hz}), 6.86(\mathrm{~d}, 1 \mathrm{H}, J=8.4 \mathrm{~Hz}), 6.90(\mathrm{~s}, 2 \mathrm{H}), 7.11(\mathrm{~s}, 1 \mathrm{H}), 7.20(\mathrm{~d}, 1 \mathrm{H}, J=8.4 \mathrm{~Hz})$, $7.89 \mathrm{ppm}(\mathrm{s}, 1 \mathrm{H}) .{ }^{13} \mathrm{C}$ NMR $\left(75.5 \mathrm{MHz}, \mathrm{CDCl}_{3}\right): \delta=14.2,21.6,28.6,33.9,56.0,56.1,60.3,60.9,68.6$, 105.0, 111.5, 111.9, 120.3, 121.3, 127.6, 133.6, 138.0, 145.7, 148.5, 149.2, 150.1, 153.3, $173.3 \mathrm{ppm} . \mathrm{m} / \mathrm{z}(\%)$ 485 (100) [M+ $\left.\mathrm{M}^{+}\right], 440$ (15), 401 (16), 153 (16), 129 (99), 101 (73), 83 (26), 55 (17).

Ethyl 6-[1-methoxy-4-(4'-(3", 4",5"-dimethoxyphenyl)oxazol-5'-yl)-2-phenoxy]hexanoate (3i). Compound $3 \mathbf{i}$ was obtained from $1 \mathrm{c}(116 \mathrm{mg}, 0.39 \mathrm{mmol}), 2 \mathbf{c}(114 \mathrm{mg}, 0.46 \mathrm{mmol})$ and $\mathrm{K}_{2} \mathrm{CO}_{3}(590 \mathrm{mg}$, $4.3 \mathrm{mmol}$ ). Yield: $86 \mathrm{mg}(0.17 \mathrm{mmol}, 44 \%) ; \mathrm{R} f=0.45$ (ethyl acetate $/ n$-hexane, $1: 1)$; colorless oil. $v_{\max }($ ATR $) / \mathrm{cm}^{-1} 2938,2870,2839,1730,1583,1515,1462,1415,1372,1327,1305,1255,1236,1173,1123$, $1022,1005,939,891,836,811,769,734,659,630 .{ }^{1} \mathrm{H} \mathrm{NMR}\left(300 \mathrm{MHz}, \mathrm{CDCl}_{3}\right): \delta=1.23(\mathrm{t}, 3 \mathrm{H}, J=7.1 \mathrm{~Hz})$, 1.4-1.5 (m, 2H), 1.6-1.8 (m, 2H), 1.8-1.9 (m, 2H), $2.30(\mathrm{~d}, 2 \mathrm{H}, J=7.3 \mathrm{~Hz}), 3.77(\mathrm{~s}, 6 \mathrm{H}), 3.86(\mathrm{~s}, 3 \mathrm{H}), 3.87$ $(\mathrm{s}, 3 \mathrm{H}), 3.91(\mathrm{t}, 2 \mathrm{H}, J=6.6 \mathrm{~Hz}), 4.10(\mathrm{q}, 2 \mathrm{H}, J=7.1 \mathrm{~Hz}), 6.86(\mathrm{~d}, 1 \mathrm{H}, J=8.4 \mathrm{~Hz}), 6.90(\mathrm{~s}, 2 \mathrm{H}), 7.11(\mathrm{~s}, 1 \mathrm{H})$, 
$7.20(\mathrm{~d}, 1 \mathrm{H}, J=8.4 \mathrm{~Hz}), 7.89 \mathrm{ppm}(\mathrm{s}, 1 \mathrm{H}) .{ }^{13} \mathrm{C} \mathrm{NMR}\left(75.5 \mathrm{MHz}, \mathrm{CDCl}_{3}\right): \delta=14.2,24.7,25.6,28.8,34.2$, 56.0, 56.1, 60.2, 60.9, 68.8, 105.0, 111.5, 111.8, 120.2, 121.3, 127.7, 133.6, 138.0, 145.7, 148.5, 149.2, 150.1, 153.3, 173.6 ppm. m/z (\%) 499 (100) [M+ $\mathrm{M}^{+}, 484$ (22), 454 (15), 357 (12), 342 (17), 249 (15), 154 (53), 143 (99), 115 (27), 97 (58), 69 (43).

\subsection{General Procedure for the Synthesis of Compounds $\mathbf{4 a - i}$}

The corresponding compound $3(0.20 \mathrm{mmol})$ was dissolved in $\mathrm{CH}_{2} \mathrm{Cl}_{2} / \mathrm{MeOH}(9 \mathrm{~mL}, 1: 2)$, hydroxylamine $(50 \%$ in water, $0.5 \mathrm{~mL}, 15 \mathrm{mmol})$ and $\mathrm{NaOH}(200 \mathrm{mg}, 5 \mathrm{mmol})$ were added and the reaction mixture was stirred at room temperature for $1 \mathrm{~h}$. The solvent was removed, the residue was dissolved in water and adjusted to $\mathrm{pH} 7-8$ with acetic acid. The aqueous phase was extracted with ethyl acetate $(2 \times 50 \mathrm{~mL})$, dried over $\mathrm{Na}_{2} \mathrm{SO}_{4}$ and concentrated in vacuum. The solid residue was recrystallized from $\mathrm{CH}_{2} \mathrm{Cl}_{2} / n$-hexane.

N-Hydroxy-4-[1-methoxy-4-(4'-(3"-chloro-4",5"-dimethoxyphenyl)oxazol-5'-yl)-2-phenoxy] butanamide (4a). Compound $4 \mathbf{a}$ was obtained from $3 \mathbf{a}(97 \mathrm{mg}, 0.20 \mathrm{mmol})$, hydroxylamine $(50 \%$ in water, $0.5 \mathrm{~mL}, 15 \mathrm{mmol})$ and $\mathrm{NaOH}(200 \mathrm{mg}, 5 \mathrm{mmol})$. Yield: $64 \mathrm{mg}(0.14 \mathrm{mmol}, 70 \%)$; colorless solid of $\mathrm{mp} 171-172{ }^{\circ} \mathrm{C} . v_{\max }(\mathrm{ATR}) / \mathrm{cm}^{-1} 3101,2942,2868,2843,1655,1593,1566,1516,1492,1463,1441$, 1401, 1364, 1328, 1258, 1242, 1228, 1206, 1179, 1168, 1141, 1117, 1100, 1073, 1052, 1024, 997, 941, 887, 866, $847,808,755,710,655,625 .{ }^{1} \mathrm{H}$ NMR $\left(300 \mathrm{MHz}, \mathrm{CDCl}_{3}\right): \delta=2.0-2.2(\mathrm{~m}, 2 \mathrm{H}), 2.4-2.5(\mathrm{~m}, 2 \mathrm{H}), 3.82(\mathrm{~s}$, $3 \mathrm{H}), 3.88(\mathrm{~s}, 3 \mathrm{H}), 3.88(\mathrm{~s}, 3 \mathrm{H}), 3.9-4.0(\mathrm{~m}, 5 \mathrm{H}), 6.90(\mathrm{~d}, 1 \mathrm{H}, J=8.5 \mathrm{~Hz}), 7.07(\mathrm{~s}, 1 \mathrm{H}), 7.15(\mathrm{~s}, 1 \mathrm{H}), 7.2-7.3$ $(\mathrm{m}, 3 \mathrm{H}), 7.89 \mathrm{ppm}(\mathrm{s}, 1 \mathrm{H}) .{ }^{13} \mathrm{C} \mathrm{NMR}\left(75.5 \mathrm{MHz}, \mathrm{CDCl}_{3}\right): \delta=24.4,30.5,56.0,56.2,60.9,68.4,110.8,111.3$, 111.5, 120.6, 121.0, 121.2, 128.3, 128.7, 132.4, 145.2, 145.8, 147.8, 149.4, 149.8, 153.9, $170.6 \mathrm{ppm} . \mathrm{m} / \mathrm{z}(\%)$ $464(4)\left[\mathrm{M}^{+}\right], 462(10)\left[\mathrm{M}^{+}\right], 447$ (27), 363 (32), 361 (100), 346 (19), 318 (10), 86 (12). Elemental analysis calculated (\%) for $\mathrm{C}_{22} \mathrm{H}_{23} \mathrm{ClN}_{2} \mathrm{O}_{7}$ : C 57.09, $\mathrm{H}$ 5.01, N 6.05. Found: C 57.06, H 5.02, N 6.04.

N-Hydroxy-5-[1-methoxy-4-(4'-(3"-chloro-4",5"-dimethoxyphenyl)oxazol-5'-yl)-2-phenoxy] pentanamide (4b). Compound $\mathbf{4 b}$ was obtained from $\mathbf{3 b}(90 \mathrm{mg}, 0.18 \mathrm{mmol})$, hydroxylamine $(50 \%$ in water, $0.5 \mathrm{~mL}, 15 \mathrm{mmol})$ and $\mathrm{NaOH}(200 \mathrm{mg}, 5 \mathrm{mmol})$. Yield: $62 \mathrm{mg}(0.13 \mathrm{mmol}, 72 \%)$; colorless solid of $\mathrm{mp} 202^{\circ} \mathrm{C}$. $v_{\max }($ ATR $) / \mathrm{cm}^{-1} 3194,2942,2870,2837,1644,1606,1592,1564,1513,1489,1460,1440$, 1400, 1364, 1326, 1255, 1230, 1206, 1176, 1140, 1107, 1047, 1019, 996, 939, 895, 853, 807, 759, 711, 657, 628, 607. ${ }^{1} \mathrm{H}$ NMR $\left(300 \mathrm{MHz}, \mathrm{CDCl}_{3}\right): \delta=1.7-1.9(\mathrm{~m}, 4 \mathrm{H}), 2.3-2.4(\mathrm{~m}, 2 \mathrm{H}), 3.82(\mathrm{~s}, 3 \mathrm{H}), 3.88(\mathrm{~s}, 3 \mathrm{H}), 3.9-4.0$ $(\mathrm{m}, 5 \mathrm{H}), 6.91(\mathrm{~d}, 1 \mathrm{H}, J=8.4 \mathrm{~Hz}), 7.04(\mathrm{~s}, 1 \mathrm{H}), 7.1-7.3(\mathrm{~m}, 3 \mathrm{H}), 7.90 \mathrm{ppm}(\mathrm{s}, 1 \mathrm{H}) .{ }^{13} \mathrm{C} \mathrm{NMR}(75.5 \mathrm{MHz}$, $\left.\mathrm{CDCl}_{3}\right): \delta=21.5,24.4,26.4,32.1,55.9,56.2,60.9,69.8,110.2,110.8,111.3,111.7,119.9,121.2,128.3,128.8$, $132.4,145.1,146.0,148.1,149.2,149.4,153.9,170.2 \mathrm{ppm} . \mathrm{m} / z(\%) 476(3)\left[\mathrm{M}^{+}\right], 461$ (42), $363(33), 361$ (100), 346 (24), 318 (16), 240 (10), 100 (41), 44 (56). Elemental analysis calculated (\%) for $\mathrm{C}_{23} \mathrm{H}_{25} \mathrm{ClN}_{2} \mathrm{O}_{7}$ : C 57.92, H 5.28, N 5.87. Found: C 57.90, H 5.26, N 5.86.

N-Hydroxy-6-[1-methoxy-4-(4'-(3"-chloro-4",5"-dimethoxyphenyl)oxazol-5'-yl)-2-phenoxy] hexanamide (4c). Compound $4 \mathrm{c}$ was obtained from $3 \mathrm{c}(58 \mathrm{mg}, 0.12 \mathrm{mmol})$, hydroxylamine $(50 \%$ in water, $0.5 \mathrm{~mL}, 15 \mathrm{mmol})$ and $\mathrm{NaOH}(200 \mathrm{mg}, 5 \mathrm{mmol})$. Yield: $44 \mathrm{mg}(0.09 \mathrm{mmol}, 75 \%)$; colorless solid of $\mathrm{mp} 189^{\circ} \mathrm{C}$. $v_{\max }(\mathrm{ATR}) / \mathrm{cm}^{-1} 3180,3120,2997,2939,2865,2837,1652,1595,1567,1513,1491,1464$, 1435, 1399, 1363, 1327, 1305, 1257, 1228, 1206, 1192, 1175, 1141, 1110, 1074, 1049, 1017, 996, 951, 895, 870, $851,823,807,777,758,729,709,657,630 .{ }^{1} \mathrm{H} \mathrm{NMR}\left(300 \mathrm{MHz}, \mathrm{CDCl}_{3}\right): \delta=1.4-1.5(\mathrm{~m}, 2 \mathrm{H}), 1.6-1.7(\mathrm{~m}$, $2 \mathrm{H}), 1.7-1.8(\mathrm{~m}, 2 \mathrm{H}), 2.1-2.2(\mathrm{~m}, 2 \mathrm{H}), 3.8-3.9(\mathrm{~m}, 11 \mathrm{H}), 6.90(\mathrm{~d}, 1 \mathrm{H}, J=8.4 \mathrm{~Hz}), 7.04(\mathrm{~s}, 1 \mathrm{H}), 7.15(\mathrm{~s}, 1 \mathrm{H})$, $7.21(\mathrm{~d}, 1 \mathrm{H}, J=8.4 \mathrm{~Hz}), 7.28(\mathrm{~s}, 1 \mathrm{H}), 7.89 \mathrm{ppm}(\mathrm{s}, 1 \mathrm{H}) .{ }^{13} \mathrm{C} \mathrm{NMR}\left(75.5 \mathrm{MHz}, \mathrm{CDCl}_{3}\right): \delta=24.9,25.5$, $28.3,32.8,56.0,56.2,60.9,68.9,110.8,111.3,111.8,119.9,120.9,121.3,128.3,129.0,132.2,145.0,146.1$, 148.4, 149.4, 150.0, 153.8, 170.9 ppm. $m / z(\%) 491(5)\left[\mathrm{M}^{+}\right], 489(14)\left[\mathrm{M}^{+}\right], 477$ (23), 475 (72), $363(23)$, 361 (100), 348 (13), 346 (36), 318 (23), 182 (13), 114 (45), 69 (51). Elemental analysis calculated (\%) for $\mathrm{C}_{24} \mathrm{H}_{27} \mathrm{ClN}_{2} \mathrm{O}_{7}$ : C 58.72, H 5.54, N 5.71. Found: C 58.70, H 5.56, N 5.69.

N-Hydroxy-4-[1-methoxy-4-(4'-(3"-bromo-4", $5^{\prime \prime}$-dimethoxyphenyl)oxazol-5'-yl)-2-phenoxy] butanamide (4d). Compound $4 \mathbf{d}$ was obtained from $3 \mathbf{d}(100 \mathrm{mg}, 0.19 \mathrm{mmol})$, hydroxylamine $(50 \%$ in water, $0.5 \mathrm{~mL}, 15 \mathrm{mmol})$ and $\mathrm{NaOH}(200 \mathrm{mg}, 5 \mathrm{mmol})$. Yield: $86 \mathrm{mg}(0.17 \mathrm{mmol}, 90 \%)$; colorless solid of mp $140-141^{\circ} \mathrm{C} . v_{\max }(\mathrm{ATR}) / \mathrm{cm}^{-1} 3192,2934,2837,1639,1592,1559,1513,1486,1463,1440,1400$, 
1362, 1255, 1229, 1179, 1140, 1107, 1076, 1041, 1021, 994, 954, 888, 856, 844, 806, 753, 733, 697, 657, 627. ${ }^{1} \mathrm{H}$ NMR $\left(300 \mathrm{MHz}, \mathrm{CDCl}_{3}\right): \delta=2.0-2.2(\mathrm{~m}, 2 \mathrm{H}), 2.4-2.5(\mathrm{~m}, 2 \mathrm{H}), 3.82(\mathrm{~s}, 3 \mathrm{H}), 3.87(\mathrm{~s}, 3 \mathrm{H}), 3.9-4.0$ $(\mathrm{m}, 5 \mathrm{H}), 6.91(\mathrm{~d}, 1 \mathrm{H}, J=8.5 \mathrm{~Hz}), 7.08(\mathrm{~s}, 1 \mathrm{H}), 7.19(\mathrm{~s}, 1 \mathrm{H}), 7.2-7.3(\mathrm{~m}, 1 \mathrm{H}), 7.43(\mathrm{~s}, 1 \mathrm{H}), 7.89 \mathrm{ppm}(\mathrm{s}$, 1H). ${ }^{13} \mathrm{C}$ NMR $\left(75.5 \mathrm{MHz}, \mathrm{CDCl}_{3}\right): \delta=24.4,30.6,56.0,56.2,60.7,68.5,111.3,111.6,117.6,120.5,121.1$, $124.0,129.4,132.3,145.9,146.2,147.8,149.4,149.8,153.8,170.5 \mathrm{ppm} . \mathrm{m} / \mathrm{z}(\%) 508(7)\left[\mathrm{M}^{+}\right], 506(8)\left[\mathrm{M}^{+}\right]$, 493 (17), 491 (20), 407 (66), 405 (67), 102 (26), 86 (32), 33 (100). Elemental analysis calculated (\%) for $\mathrm{C}_{22} \mathrm{H}_{23} \mathrm{BrN}_{2} \mathrm{O}_{7}$ : C 52.08, H 4.57, N 5.52. Found: C 52.06, H 4.56, N 5.50.

N-Hydroxy-5-[1-methoxy-4-(4'-(3"'-bromo-4",5"-dimethoxyphenyl)oxazol-5'-yl)-2-phenoxy] pentanamide (4e). Compound $4 \mathbf{e}$ was obtained from $3 \mathbf{e}(110 \mathrm{mg}, 0.21 \mathrm{mmol})$, hydroxylamine $(50 \%$ in water, $0.5 \mathrm{~mL}, 15 \mathrm{mmol})$ and $\mathrm{NaOH}(200 \mathrm{mg}, 5 \mathrm{mmol})$. Yield: $74 \mathrm{mg}(0.14 \mathrm{mmol}, 67 \%)$; colorless solid of $\mathrm{mp} 152-153{ }^{\circ} \mathrm{C} . v_{\max }(\mathrm{ATR}) / \mathrm{cm}^{-1} 3186,2940,1641,1593,1563,1515,1487,1401,1361,1327,1257$, $1231,1181,1162,1143,1106,1074,1040,1022,993,950,894,858,845,802,753,700,655,628 .{ }^{1} \mathrm{H}$ NMR $\left(300 \mathrm{MHz}, \mathrm{CDCl}_{3}\right): \delta=1.8-1.9(\mathrm{~m}, 4 \mathrm{H}), 2.3-2.5(\mathrm{~m}, 2 \mathrm{H}), 3.82(\mathrm{~s}, 3 \mathrm{H}), 3.87(\mathrm{~s}, 3 \mathrm{H}), 3.9-4.0(\mathrm{~m}, 5 \mathrm{H}), 6.90$ $(\mathrm{d}, 1 \mathrm{H}, J=8.5 \mathrm{~Hz}), 7.05(\mathrm{~s}, 1 \mathrm{H}), 7.2-7.3(\mathrm{~m}, 2 \mathrm{H}), 7.44(\mathrm{~s}, 1 \mathrm{H}), 7.89 \mathrm{ppm}(\mathrm{s}, 1 \mathrm{H}) .{ }^{13} \mathrm{C}$ NMR $(75.5 \mathrm{MHz}$, $\left.\mathrm{CDCl}_{3}\right): \delta=24.4,26.4,32.1,55.9,56.2,60.8,69.8,110.1,111.3,111.6,117.6,119.9,121.2,124.0,129.5$, $132.3,146.0,146.2,148.1,149.2,149.4,153.7,170.3 \mathrm{ppm} . \mathrm{m} / \mathrm{z}(\%) 521(5)\left[\mathrm{M}^{+}\right], 519(5)\left[\mathrm{M}^{+}\right], 505(24)$, 407 (100), 405 (95), 392 (24), 390 (24), 364 (12), 362 (13), 100 (93), 72 (67), 55 (54). Elemental analysis calculated (\%) for $\mathrm{C}_{23} \mathrm{H}_{25} \mathrm{BrN}_{2} \mathrm{O}_{7}$ : C 52.99, $\mathrm{H} 4.83$, N 5.37. Found: C 52.97, $\mathrm{H}$ 4.82, N 5.35.

N-Hydroxy-6-[1-methoxy-4-(4'-(3"-bromo-4",5"-dimethoxyphenyl)oxazol-5'-yl)-2-phenoxy] hexanamide (4f). Compound $4 \mathbf{f}$ was obtained from $3 \mathbf{f}(80 \mathrm{mg}, 0.15 \mathrm{mmol})$, hydroxylamine $(50 \%$ in water, $0.5 \mathrm{~mL}, 15 \mathrm{mmol})$ and $\mathrm{NaOH}(200 \mathrm{mg}, 5 \mathrm{mmol})$. Yield: $75 \mathrm{mg}(0.14 \mathrm{mmol}, 93 \%)$; colorless solid of $\mathrm{mp} 115-117^{\circ} \mathrm{C}$. $v_{\max }(\mathrm{ATR}) / \mathrm{cm}^{-1} 3190,2938,2865,1647,1591,1558,1512,1485,1463,1400,1362$, 1325, 1254, 1229, 1203, 1176, 1139, 1107, 1042, 998, 939, 853, 807, 775, 753, 697, 658, 628. ${ }^{1} \mathrm{H}$ NMR $\left(300 \mathrm{MHz}, \mathrm{CDCl}_{3}\right): \delta=1.4-1.5(\mathrm{~m}, 2 \mathrm{H}), 1.6-1.7(\mathrm{~m}, 2 \mathrm{H}), 1.7-1.8(\mathrm{~m}, 4 \mathrm{H}), 2.2-2.3(\mathrm{~m}, 2 \mathrm{H}), 3.80(\mathrm{~s}, 3 \mathrm{H})$, $3.8-3.9(\mathrm{~m}, 8 \mathrm{H}), 6.89(\mathrm{~d}, 1 \mathrm{H}, J=8.5 \mathrm{~Hz}), 7.05(\mathrm{~s}, 1 \mathrm{H}), 7.2-7.3(\mathrm{~m}, 2 \mathrm{H}), 7.43(\mathrm{~s}, 1 \mathrm{H}), 7.89 \mathrm{ppm}(\mathrm{s}, 1 \mathrm{H}) .{ }^{13} \mathrm{C}$ $\operatorname{NMR}\left(75.5 \mathrm{MHz}, \mathrm{CDCl}_{3}\right): \delta=25.0,25.5,28.3,32.8,56.0,56.1,60.8,68.9,111.2,111.6,111.7,117.6,119.9$, $120.9,124.1,129.6,132.0,146.0,146.1,148.4,149.4,150.0,153.7,171.0$ ppm. $m / z(\%) 536(1)\left[\mathrm{M}^{+}\right], 534(1)$ [M+ $], 521$ (91), 519 (100), 407 (53), 405 (51), 392 (17), 390 (17), 364 (7), 362 (8), 282 (7), 265 (12), 243 (7), 194 (16), 167 (28), 114 (36), 69 (17), 44 (30). Elemental analysis calculated (\%) for $\mathrm{C}_{24} \mathrm{H}_{27} \mathrm{BrN}_{2} \mathrm{O}_{7}$ : C 53.84, H 5.08, N 5.23. Found: C 53.82, H 5.06, N 5.22.

N-Hydroxy-4-[1-methoxy-4-(4'-(3", 4",5"-trimethoxyphenyl)oxazol-5'-yl)-2-phenoxy]butanamide (4g). Compound $4 \mathbf{g}$ was obtained from $3 \mathrm{~g}(119 \mathrm{mg}, 0.25 \mathrm{mmol})$, hydroxylamine ( $50 \%$ in water, $0.5 \mathrm{~mL}$, $15 \mathrm{mmol})$ and $\mathrm{NaOH}(200 \mathrm{mg}$, $5 \mathrm{mmol})$. Yield: $74 \mathrm{mg}(0.16 \mathrm{mmol}, 64 \%)$; colorless solid of $\mathrm{mp}$ $121-123^{\circ} \mathrm{C} . v_{\max }(\mathrm{ATR}) / \mathrm{cm}^{-1} 3194,2935,2837,1658,1583,1515,1454,1415,1373,1256,1238,1173,1123$, 1020, 1002, 939, 884, 838, 813, 767, 734, 658, 628. ${ }^{1} \mathrm{H}$ NMR (300 MHz, $\left.\mathrm{CDCl}_{3}\right) \delta 2.0-2.2(\mathrm{~m}, 2 \mathrm{H}), 2.3-2.4$ $(\mathrm{m}, 2 \mathrm{H}), 3.76(\mathrm{~s}, 6 \mathrm{H}), 3.85(\mathrm{~s}, 3 \mathrm{H}), 3.9-4.0(\mathrm{~m}, 5 \mathrm{H}), 4.15(\mathrm{q}, 2 \mathrm{H}, J=7.1 \mathrm{~Hz}), 6.8-6.9(\mathrm{~m}, 3 \mathrm{H}), 7.05(\mathrm{~s}, 1 \mathrm{H})$, 7.2-7.3 (m, 1H), $7.90 \mathrm{ppm}(\mathrm{s}, 1 \mathrm{H}) .{ }^{13} \mathrm{C} \mathrm{NMR}\left(75.5 \mathrm{MHz}, \mathrm{CDCl}_{3}\right): \delta=24.5,30.2,56.0,56.2,61.0,68.2$, $105.2,110.0,111.4,120.4,121.3,127.8,133.7,145.5,147.7,149.3,149.7,153.3,170.5$ ppm. $\mathrm{m} / \mathrm{z}(\%) 458$ (4) $\left[\mathrm{M}^{+}\right], 443$ (100), 428 (26), 357 (98), 342 (62), 314 (17), 236 (16), 195 (18), 151 (12), 86 (22), 44 (29). Elemental analysis calculated (\%) for $\mathrm{C}_{23} \mathrm{H}_{26} \mathrm{~N}_{2} \mathrm{O}_{8}$ : C 60.26, $\mathrm{H}$ 5.72, N 6.11. Found: C 60.23, H 5.70, N 6.08.

N-Hydroxy-5-[1-methoxy-4-(4'-(3",4",5"-trimethoxyphenyl)oxazol-5'-yl)-2-phenoxy]pentanamide (4h). Compound $4 \mathrm{~h}$ was obtained from $3 \mathrm{~h}(98 \mathrm{mg}, 0.20 \mathrm{mmol})$, hydroxylamine $(50 \%$ in water, $0.5 \mathrm{~mL}$, $15 \mathrm{mmol})$ and $\mathrm{NaOH}(200 \mathrm{mg}$, $5 \mathrm{mmol})$. Yield: $72 \mathrm{mg}(0.15 \mathrm{mmol}, 76 \%)$; colorless solid of $\mathrm{mp}$ $118-120^{\circ} \mathrm{C} . v_{\max }(\mathrm{ATR}) / \mathrm{cm}^{-1} 3191,2937,2870,2843,1657,1584,1515,1454,1415,1373,1306,1255,1239$, $1173,1123,1022,838,811,768,734,658,629 .{ }^{1} \mathrm{H}$ NMR $\left(300 \mathrm{MHz}, \mathrm{CDCl}_{3}\right): \delta=1.8-1.9(\mathrm{~m}, 4 \mathrm{H}), 2.2-2.3$ $(\mathrm{m}, 2 \mathrm{H}), 3.78(\mathrm{~s}, 6 \mathrm{H}), 3.8-3.9(\mathrm{~m}, 5 \mathrm{H}), 3.94(\mathrm{~s}, 3 \mathrm{H}), 6.8-6.9(\mathrm{~m}, 3 \mathrm{H}), 7.02(\mathrm{~s}, 1 \mathrm{H}), 7.2-7.3(\mathrm{~m}, 1 \mathrm{H}), 7.90 \mathrm{ppm}$ (s, 1H). ${ }^{13} \mathrm{C} \mathrm{NMR}\left(75.5 \mathrm{MHz}, \mathrm{CDCl}_{3}\right): \delta=24.0,26.6,32.0,55.9,56.2,61.0,69.5,105.3,110.4,111.2,119.9$, $121.5,127.9,133.7,137.8,145.6,148.0,149.1,149.3,153.3,170.1$ ppm. $\mathrm{m} / \mathrm{z}(\%) 472(3)\left[\mathrm{M}^{+}\right], 457(100), 442$ 
(10), 357 (73), 342 (34), 314 (11), 100 (17), 44 (12). Elemental analysis calculated (\%) for $\mathrm{C}_{24} \mathrm{H}_{28} \mathrm{~N}_{2} \mathrm{O}_{8}$ : C 61.01, H 5.97, N 5.93. Found: C 61.04, H 5.95, N 5.90.

N-Hydroxy-6-[1-methoxy-4-(4'-(3", $4^{\prime \prime}, 5^{\prime \prime}$-trimethoxyphenyl)oxazol-5'-yl)-2-phenoxy]hexanamide

(4i). Compound $4 \mathbf{i}$ was obtained from $3 \mathbf{i}(73 \mathrm{mg}, 0.15 \mathrm{mmol})$, hydroxylamine ( $50 \%$ in water, $0.5 \mathrm{~mL}$, $15 \mathrm{mmol})$ and $\mathrm{NaOH}(200 \mathrm{mg}, 5 \mathrm{mmol})$. Yield: $52 \mathrm{mg}(0.11 \mathrm{mmol}, 73 \%)$; colorless solid of $\mathrm{mp} 114-116$ ${ }^{\circ} \mathrm{C} . v_{\max }(\mathrm{ATR}) / \mathrm{cm}^{-1} 3211,2936,2870,2837,1651,1584,1515,1455,1414,1372,1331,1306,1255$, $1238,1173,1122,1019,1001,939,892,836,810,767,732,658,628 .{ }^{1} \mathrm{H} \mathrm{NMR}\left(300 \mathrm{MHz}, \mathrm{CDCl}_{3}\right): \delta=$ 1.3-1.4 (m, 2H), 1.5-1.7 (m, 4H), 2.1-2.2 (m, 2H), $3.76(\mathrm{~s}, 6 \mathrm{H}), 3.8-3.9(\mathrm{~m}, 8 \mathrm{H}), 6.8-6.9(\mathrm{~m}, 3 \mathrm{H}), 7.03(\mathrm{~s}$, 1H), 7.2-7.3 (m, 1H), 7.90 ppm (s, 1H). ${ }^{13} \mathrm{C} \mathrm{NMR}\left(75.5 \mathrm{MHz}, \mathrm{CDCl}_{3}\right): \delta=25.0,25.4,28.3,32.8,56.0$, 56.1, 61.0, 68.8, 105.2, 111.5, 111.6, 119.8, 121.2, 127.9, 133.4, 137.6, 145.7, 148.2, 149.3, 149.8, 153.2,

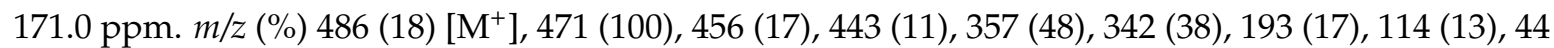
(21). Elemental analysis calculated (\%) for $\mathrm{C}_{25} \mathrm{H}_{30} \mathrm{~N}_{2} \mathrm{O}_{8}$ : C 61.72, H 6.22, N 5.76. Found: $\mathrm{C} 61.70, \mathrm{H}$ $6.21, \mathrm{~N} 5.74$.

\subsection{Ester Hydrolysis of $3 g$ to Carboxylic Acid $4 j$}

4-[1-Methoxy-4-(4'-(3",4",5"-trimethoxyphenyl)oxazol-5'-yl)-2-phenoxy]butyric acid (4j). Compound $3 \mathrm{~g}(119 \mathrm{mg}, 0.25 \mathrm{mmol})$ was dissolved in $\mathrm{MeOH}(10 \mathrm{~mL})$, aqueous $\mathrm{NaOH}(1 \mathrm{M}, 10 \mathrm{~mL})$ was added and the reaction mixture was stirred at room temperature for $24 \mathrm{~h}$. The solution was acidified with aqueous $\mathrm{HCl}(1 \mathrm{M}$, to $\mathrm{pH}<2)$ and the resulting precipitate was collected, washed with water, and dried in vacuum. Yield: $75 \mathrm{mg}(0.17 \mathrm{mmol}, 68 \%)$; colorless solid of $\mathrm{mp} 209-210^{\circ} \mathrm{C}$. $v_{\max }($ ATR $) / \mathrm{cm}^{-1} 3134,2940,2873,2835,2538,1728,1606,1586,1519,1474,1446,1414,1372,1316,1274$, 1251, 1237, 1196, 1173, 1147, 1128, 1112, 1068, 1043, 1031, 1022, 1007,962, 946, 883, 855, 840, 804, 769, 761, 736, 674, 654, 630, 623. ${ }^{1} \mathrm{H}$ NMR $\left(300 \mathrm{MHz}, \mathrm{CDCl}_{3}\right): \delta=2.0-2.2(\mathrm{~m}, 2 \mathrm{H}), 2.56(\mathrm{t}, 2 \mathrm{H}, J=7.2 \mathrm{~Hz}), 3.76(\mathrm{~s}$, $6 \mathrm{H}), 3.86(\mathrm{~s}, 3 \mathrm{H}), 3.87(\mathrm{~s}, 3 \mathrm{H}), 3.98(\mathrm{t}, 1 \mathrm{H}, J=6.3 \mathrm{~Hz}), 6.86(\mathrm{~d}, 1 \mathrm{H}, J=8.5 \mathrm{~Hz}), 6.88(\mathrm{~s}, 2 \mathrm{H}), 7.12(\mathrm{~s}, 1 \mathrm{H})$, $7.22(\mathrm{~d}, 1 \mathrm{H}, J=8.5 \mathrm{~Hz}), 7.91 \mathrm{ppm}(\mathrm{s}, 1 \mathrm{H}) .{ }^{13} \mathrm{C} \mathrm{NMR}\left(75.5 \mathrm{MHz}, \mathrm{CDCl}_{3}\right): \delta=24.2,30.2,56.0,56.1,60.9$, 67.8, 105.1, 111.6, 112.1, 120.5, 121.3, 127.6, 133.5, 137.9, 145.6, 148.2, 149.3, 150.1, 153.3, 177.0 ppm. $\mathrm{m} / \mathrm{z}$ (ESI, \%) $466.2(27)\left[\mathrm{M}^{+}+\mathrm{Na}\right], 444.2(100)\left[\mathrm{M}^{+}\right]$. Elemental analysis calculated (\%) for $\mathrm{C}_{23} \mathrm{H}_{25} \mathrm{NO}_{8}$ : C 62.30, H 5.68, N 3.16. Found: C 62.26, H 5.65, N 3.08.

\subsection{Biological Evaluations}

\subsubsection{Cell Lines and Culture Conditions}

HT-29 (ACC-299), HCT-116 (ACC-581) and DLD-1 (ACC-278) colon carcinoma, MCF-7 (ACC-115) breast carcinoma, KB-V1 (ACC-149), 518A2 (Department of Radiotherapy and Radiobiology, University Hospital Vienna) melanoma and Ea.Hy926 (ATCC no. CRL-2922) HUVEC derived endothelial hybrid cells line were grown in Dulbecco's Modified Eagle Medium (DMEM; Biochrom), high glucose supplemented with $10 \%(v / v)$ fetal bovine serum (FBS; Biochrom.) and $1 \%(v / v)$ Antibiotic-Antimycotic solution (anti-anti; Thermo Scientific). HDFa human dermal fibroblasts (ATCC: PCS-201-012 ${ }^{\mathrm{TM}}$ ) were grown in DMEM supplemented with 10\% FBS, $1 \%$ anti-anti and $2 \mathrm{mM}$ glutamine. The cells were incubated at $37{ }^{\circ} \mathrm{C}, 5 \% \mathrm{CO}_{2}, 95 \%$ humidified atmosphere. By repeated addition of topotecan or vinblastine at the maximum tolerated dose to the cell medium of MCF-7 and KB-V1 cells, the cells were rendered multidrug-resistant, indicated as MCF-7 $7^{\mathrm{Topo}}$ and $\mathrm{KB}-\mathrm{V} 1^{\mathrm{Vbl}}$, respectively. They were serially passaged following trypsinization by using $0.05 \%$ trypsin $/ 0.02 \%$ EDTA (Biochrom). Mycoplasma contamination was routinely monitored, and only mycoplasma-free cultures were used.

\subsubsection{MTT Assay}

MTT [3-(4,5-dimethylthiazol-2-yl)-2,5-diphenyltetrazolium bromide] (ABCR) was used to determine the cytotoxicity of test compounds as previously described [53]. Briefly, HDFa human dermal fibroblasts and Ea.Hy926 endothelial hybrid cells (both $1 \times 10^{5}$ cells $/ \mathrm{mL}, 100 \mu \mathrm{L} /$ well), 518A2 melanoma, KB-V1 ${ }^{\mathrm{Vbl}}$ cervix carcinoma, MCF-7 ${ }^{\text {Topo }}$ breast carcinoma, HT-29, DLD-1 and 
HCT-116 colon carcinoma (all $5 \times 10^{4}$ cells $/ \mathrm{mL}, 100 \mu \mathrm{L} /$ well) were grown in 96-well culture plates for $24 \mathrm{~h}$. Then, various concentrations of the test compounds were added and the cells were incubated for $24-72 \mathrm{~h}$ at $37^{\circ} \mathrm{C}$. After adding $12.5 \mu \mathrm{L}$ of a $0.5 \%$ MTT solution in PBS (final concentration $0.05 \%$ ) to cell medium, microplates were incubated for $2 \mathrm{~h}$ and subsequently swiftly turned to discard the medium. The precipitate of formazan crystals was then dissolved in a 10\% solution of SDS in DMSO containing $0.6 \%$ acetic acid. To ensure complete dissolution of formazan, microplates were incubated for at least $4 \mathrm{~h}$ at $37^{\circ} \mathrm{C}$. Finally, the absorbance at $\lambda=570 \mathrm{~nm}$ (formazan) and $630 \mathrm{~nm}$ (background) was measured using a microplate reader (Tecan F200). All experiments were carried out in quadruplicate and the percentage of viable cells was calculated as the mean \pm SD with controls set to $100 \%$. Selected graphs of MTT assays can be found in the Supporting Information (Figure S8).

\subsubsection{Tubulin Polymerization Assay}

An amount of $50 \mu \mathrm{L}$ of Brinkley's buffer 80 (BRB80) supplemented with $20 \%$ glycerol and $3 \mathrm{mM}$ GTP was given in a black 96-well half-area plate with clear bottom. Then, test compounds $4 \mathbf{d}-\mathbf{f}$ (final concentration: $5 \mu \mathrm{M}$, or $10 \mu \mathrm{M}$ ) or vehicle (DMSO) were added. After adding $50 \mu \mathrm{L}$ tubulin in BRB80 $(10 \mathrm{mg} / \mathrm{mL})$ was pipetted in the wells and immediately placed in a pre-heated microplate reader (Tecan). The polymerization was determined turbidimetrically at $37^{\circ} \mathrm{C}$ by measuring the absorption at $340 \mathrm{~nm}$ for $120 \mathrm{~min}$ in intervals of $5 \mathrm{~min}$. Values were normally distributed for each group (Shapiro-Wilk test, $p>0.05$ ) and there was homogeneity of variance (Levene's test, $p>0.05$ ). The one-tailed Dunnett post-hoc test revealed significant inhibition of tubulin polymerization $(p \leq$ 0.001) for CA-4 and $4 \mathrm{~d}$ compared to controls.

\subsubsection{Immunofluorescence Staining of Microtubule Cytoskeleton}

518A2 melanoma cells $\left(5 \times 10^{4}\right.$ cells $/ \mathrm{mL}, 500 \mu \mathrm{L} /$ well $)$ or Ea.Hy926 endothelial hybrid cells $(7.5$ $\times 10^{4}$ cells $/ \mathrm{mL}, 500 \mu \mathrm{L} /$ well) were seeded in 24-well plates on small glass coverslips and grown for $24 \mathrm{~h}$. Then, the cells were exposed to the test compounds for $24 \mathrm{~h}$. After washing the cells once with PBS, they were fixed in 3.7\% formaldehyde in PBS (20 min, rt), and permeabilized and blocked in $1 \%$ BSA and $0.1 \%$ triton X-100 in PBS (30 min, rt). Then, the cells were incubated with monoclonal mouse anti-alpha-tubulin antibody $\left(1 \mathrm{~h}, 37^{\circ} \mathrm{C}\right)$. After washing the cells for three times with PBS, the cells were exposed to the secondary anti-mouse 488 antibody conjugate $(1 \mathrm{~h}, \mathrm{rt}$, in the dark). Then, the cells were washed for three times with PBS and once with water. The glass coverslips were mounted in 4-88 based mounting medium supplemented with $1 \mu \mathrm{g} / \mathrm{mL}$ DAPI for counterstaining the nuclei and $2.5 \%$ DABCO. Alterations of the microtubule were documented by a Zeiss Imager A1 AX10 fluorescence microscope (400× magnification).

\subsubsection{HDAC Inhibition}

The HDAC inhibitory potential of the novel compounds was determined by utilizing the deacetylase activity of recombinant human HDAC1 (HDAC1 Inhibitor Screening Assay Kit; Cayman Chemicals) or HDAC6 (HDAC6 Inhibitor Screening Kit (Fluorometric); Biovision) towards the corresponding synthetic acetylated-peptide substrates resulting in the release of a fluorescent product. The assays were performed according to manufacturer's description of the in commercially available assay kits. The fluorescence intensity (HDAC1: $\lambda_{\mathrm{ex}}=352 \mathrm{~nm}, \lambda_{\mathrm{em}}=452 \mathrm{~nm}$; HDAC6: $\lambda_{\mathrm{ex}}=380 \mathrm{~nm}$, $\lambda_{\mathrm{em}}=510 \mathrm{~nm}$ ) as a measure of enzyme activity was measured at $37^{\circ} \mathrm{C}$ with a microplate reader (Tecan). The $\mathrm{IC}_{50}$ values were derived from dose-response curves and are expressed as the means $\pm \mathrm{SD}$ of two independent experiments. A two-tailed t-test was performed, revealing significant differences $(p<0.0001)$ in HDAC6-inhibition for $\mathbf{4} \mathbf{e}-\mathbf{f}$ compared with $\mathbf{4} \mathbf{d}$ as well as for $\mathbf{4} \mathbf{d}$ and $\mathbf{4} \mathbf{f}$ compared with $4 \mathbf{e}$ and in HDAC1-inhibition for $\mathbf{4 d - e}$ compared with $\mathbf{4 f}$. The difference in HDAC1 $\mathrm{IC}_{50}$ values of $\mathbf{4 d}$ compared with $4 \mathbf{e}$ were not significant. 


\subsubsection{Western Blot Analyses}

For the microtubule acetylation blots, 518A2 melanoma cells $\left(5 \times 10^{4}\right.$ cells $/ \mathrm{mL}, 3 \mathrm{~mL} /$ well $)$ were grown in 6-well plates for $24 \mathrm{~h}$ and then incubated with vehicle (DMSO), SAHA $(10 \mu \mathrm{M})$, or $4 \mathrm{f}(4,5$, and $6 \mu \mathrm{M})$ for $24 \mathrm{~h}$. After harvesting the cells by trypsination, they were pelleted by centrifugation $(300 \times \mathrm{g}, 5 \mathrm{~min})$ followed by cell lysis in $100 \mu \mathrm{L}$ lysis buffer $(20 \mathrm{mM}$ DTT, 200 $\mu \mathrm{M}$ sodium vanadate, $50 \mathrm{mM}$ Tris/ $\mathrm{HCl}, 1 \%$ triton $\mathrm{X}-100,150 \mathrm{mM} \mathrm{NaCl}, \mathrm{pH} 7.4$ ) for $10 \mathrm{~min}$ on ice. The cell lysates were mixed with $100 \mu \mathrm{L}$ of $2 \times$ Laemmli buffer $(125 \mathrm{mM}$ Tris-HCl, $4 \%$ SDS, $20 \%$ glycerol, $10 \% \beta$-mercapto-ethanol, $\mathrm{pH} 6.8$ ) and boiled $\left(95^{\circ} \mathrm{C}, 10 \mathrm{~min}\right)$. Equal amounts of total protein were subjected to $10 \%$ SDS-polyacrylamide gel electrophoresis (SDS-PAGE) and transferred to polyvinylidene difluoride membranes (PVDF, Carl Roth). For subsequent analysis of acetylated protein and of alpha-tubulin which was used as a loading control, membranes were blocked and incubated with primary antibody solutions in 5\% bovine serum albumin in $1 \times$ TBS or $5 \%$ milk powder in PBS, respectively. The protein bands were visualized by chemoluminescence (secondary antibody-HRP conjugates, ECL detection system; Cell Signaling) using a LAS-3000 imager (Fujifilm).

For the cell cycle protein blots, 518A2 melanoma cells $(2 \times 106$ cells $/ \mathrm{mL}, 10 \mathrm{~mL} /$ well $)$ were grown in $10 \mathrm{~cm}$ dishes for $24 \mathrm{~h}$ and then incubated with $4 \mathrm{~d}(0.15-4 \mu \mathrm{M})$ or SAHA $(5 \mu \mathrm{M})$ for $24 \mathrm{~h}$. After harvesting and lysing of the cells, western blotting was performed as described before [54]. For subsequent analysis, the protein-loaded membranes were incubated with antibodies directed against p21 (Abcam ab109199), p27 (Abcam ab109199), cyclin D1 (Cell Signaling 29225) and GADPH (Santa Cruz sc25778) in 1:1000 dilutions. After incubation with horseradish peroxidase-coupled anti-IgG antibodies (1:10,000; Amersham), the blot was developed using the Celvin-S developer (Biostep) and the software SnapAndGo 1.8.1.

\subsubsection{Immunofluorescence Staining of F-Actin}

518A2 melanoma cells $\left(5 \times 10^{4}\right.$ cells $/ \mathrm{mL}, 500 \mu \mathrm{L} /$ well $)$ were seeded in 24 -well plates on small glass coverslips and grown for $24 \mathrm{~h}$ at $37^{\circ} \mathrm{C}$. Then, the cells were treated with $4 \mathrm{~d}(0.5 \mu \mathrm{M}), 4 \mathrm{e}(1.5 \mu \mathrm{M}), 4 \mathrm{f}(4$ $\mu \mathrm{M})$, and vehicle (DMSO) for $24 \mathrm{~h}$. After washing the cells once with PBS at $37^{\circ} \mathrm{C}$, they were fixed with $3.7 \%$ formaldehyde solution in PBS (pH 7.0) for $10 \mathrm{~min}$ at room temperature. Then, the cells were washed with PBS and permeabilized with $0.5 \%$ Triton X-100 in PBS for $5 \mathrm{~min}$ at room temperature. After washing with PBS, the cells were incubated with $200 \mu \mathrm{L}$ of a $0.1 \mu \mathrm{M}$ Acti-stain ${ }^{\mathrm{TM}} 488$ phalloidin solution in PBS for $30 \mathrm{~min}$ at room temperature in the dark. Then, the cells were washed three times with PBS and once with water, and the glass coverslips mounted in 4-88-based mounting medium containing $1 \mu \mathrm{g} / \mathrm{mL}$ DAPI for counterstaining the nuclei and $2.5 \% \mathrm{DABCO}$. The effects on the actin cytoskeleton were documented by a Zeiss Imager A1 AX10 fluorescence microscope (400× magnification).

\subsubsection{Cell Cycle Analysis}

The 518A2 melanoma cells ( $3 \mathrm{~mL} /$ well; $5 \times 10^{4}$ cells $/ \mathrm{mL}$ ) were grown on 6-well tissue culture plates for $24 \mathrm{~h}$. After treatment with $4 \mathbf{d}(150$, and $200 \mathrm{nM}), 4 \mathbf{e}(0.8$, and $1 \mu \mathrm{M}), 4 \mathbf{f}(2$, and $3 \mu \mathrm{M})$, or DMSO (control) for another $24 \mathrm{~h}$, cells were fixed $\left(70 \% \mathrm{EtOH}, 24 \mathrm{~h}, 4{ }^{\circ} \mathrm{C}\right)$, washed with PBS and incubated with propidium iodide (PI; Carl Roth) staining solution ( $50 \mu \mathrm{g} / \mathrm{mL}$ PI, $0.1 \%$ sodium citrate, $50 \mu \mathrm{g} / \mathrm{mL}$ RNase A in PBS) for $30 \mathrm{~min}$ at $37^{\circ} \mathrm{C}$. The fluorescence intensity of 10,000 single cells was measured at $\lambda_{\mathrm{em}}=570 \mathrm{~nm}\left(\lambda_{\mathrm{ex}}=488 \mathrm{~nm}\right.$ laser source) with a Beckmann Coulter Cytomics FC 500 flow cytometer. The percentages of cells in the different phases of the cell cycle (G1, S and G2/M phase) were determined using the CXP Analysis software (Beckmann Coulter). The percentage of apoptotic cells was derived from sub-G1 peaks. Data was normally distributed for each group (Shapiro-Wilk test, $p>0.05$ ). Since homogeneity of variance (Levene's test, $p<0.05$ ) was violated, a correction was calculated for Anova (Welch test). The two-tailed Games-Howell's post-hoc test revealed the significant alteration $(p \leq 0.05)$ of the population of cells in G1 in 518A2 melanoma cells treated with 4d-f compared with vehicle-treated controls. 


\subsubsection{In Vivo Toxicity}

In vivo toxicity of $\mathbf{4 d}$ was studied in nude mice (Charles River Laboratories, Sulzfeld, Germany). These experiments were carried out following the institutional guidelines. $4 \mathbf{d}$ was formulated in $10 \%$ Tween $80 / 10 \%$ ethanol $/ 80 \%$ saline for administration. One mouse $(32 \mathrm{~g})$ was treated once with $1 \times$ $100 \mathrm{mg} / \mathrm{kg}$ body weight (i.p.), another mouse $(30 \mathrm{~g})$ was treated once with $1 \times 200 \mathrm{mg} / \mathrm{kg}$ body weight (orally) of $4 \mathbf{d}$ and then both mice were observed for two weeks. The body weight of the mice was assessed daily under therapy.

\subsection{In Silico Evaluation}

\subsubsection{Proteins and Compound Structures}

The protein structures for tubulin, HDAC1, and HDAC6 used in the docking studies were obtained from the Protein Data Bank (Table 7, PDB, www.rcsb.org, accessed 6 March 2018) [55]. One representative per protein was selected for the docking studies based on the following criteria: The protein should be co-crystallized with a ligand most similar to the ligands from which the studied hybrid compounds $\mathbf{4} \mathbf{d}-\mathbf{f}$ were derived (combretastatin A- 4 for tubulin and hydroxamic acids for HDACs) [56]. Among these, the structures with the best resolutions were selected.

Table 7. Selection of PBD structures used for docking.

\begin{tabular}{ccccc}
\hline & PDB & Chain & Res. & Original Ligand \\
\hline Tubulin & $5 \mathrm{LYJ}$ & $\mathrm{A} \& \mathrm{~B}$ & $2.4 \AA$ & Combretastatin A-4 \\
HDAC1 & $5 \mathrm{ICN}$ & $\mathrm{B}$ & $3.3 \AA$ & H4K16Hx \\
HDAC6 & $5 \mathrm{EDU}$ & $\mathrm{A}$ & $2.8 \AA$ & Trichostatin A \\
\hline
\end{tabular}

\subsubsection{Initial Docking with LeadIT/FlexX}

To generate initial predictions of binding positions, called docking poses, FlexX (included in LeadIT 2.2.0, which was kindly provided by BioSolveIT, www.biosolveit.de/LeadIT), was used [57]. The PDB structures were prepared as follows: For tubulin, chains A and B of 5LYJ, for HDAC1, chain B of 5ICN, and for HDAC6, chain A of 5EDU were chosen [47,50,51]. The binding pockets were defined with the co-crystallized ligands as a reference ligand, including all amino acids within a radius of $10 \AA$ for the HDAC structures and $6.5 \AA$ for tubulin. The metal coordination of the zinc ion in both HDAC structures was set to 'spherical' and zinc was defined as an essential pharmacophore for guided docking. All other settings for the receptor definition were used as default. The docking library contained compounds $4 \mathbf{d}-\mathbf{f}$ as well as the crystal structure's original ligand. For HDAC1 and HDAC6 vorinostat, a known HDAC inhibitor, was added to the library. The docking strategy, scoring and chemical parameters were kept as default. Only the maximum number of solutions per iteration and the maximum number of solutions per fragmentation were increased to 1000 steps each.

\subsubsection{Pose Optimization with SeeSAR}

Final pose optimization and affinity estimation was performed with SeeSAR 6.1, also kindly provided by BioSolveIT (www.biosolveit.de/SeeSAR). The best poses from the LeadIT docking were imported and were used for binding site definition. For each compound, 10 new poses were generated, and all were evaluated with the built in HYDE scoring function [58]. The poses with the best estimated affinities were chosen for further analysis.

\subsubsection{Additional Software Used}

PyMOL was used to analyze, compare, and visualize the binding pose predictions, as well as to create the 3D images [59]. 
Supplementary Materials: Supplementary Materials can be found at http:/ / www.mdpi.com/1422-0067/20/2/ $383 /$ s1.

Author Contributions: Investigation, F.S., A.D., and T.M.; Compound preparation, B.B.; Docking, L.C.G. and A.V.; Writing-Original Draft Preparation, F.S., L.C.G., A.V., and B.B.; Writing-Review \& Editing, R.S. and M.H.; Supervision, R.S., A.V., and M.H.; Funding Acquisition, R.S., A.V., and M.H.

Funding: R.S. was funded by the Deutsche Forschungsgemeinschaft grant number Scho 402/12. A.D. was funded by a grant of the Else-Kroener Fresenius Stiftung grant number 2016_A47. A.V. announces funding from the Bundesministerium für Bildung und Forschung grant number 031A262C. We acknowledge support from the German Research Foundation (DFG) and the Open Access Publication Fund of Charité-Universitätsmedizin Berlin.

Conflicts of Interest: The authors declare no conflict of interest.

$\begin{array}{ll}\text { Abbreviations } \\ \text { CA-4 } & \text { Combretastatin A-4 } \\ \text { DMEM } & \text { Dulbecco's modified Eagle medium } \\ \text { EMT } & \text { Epithelial-to-mesenchymal transition } \\ \text { FBS } & \text { Fetal bovine serum } \\ \text { HDAC } & \text { Histone deacetylase } \\ \text { HDACi } & \text { HDAC inhibitor } \\ \text { HRP } & \text { Horseradish peroxidase } \\ \text { MDA } & \text { Microtubule disrupting agent } \\ \text { PI } & \text { Propidium iodide } \\ \text { ROS } & \text { Reactive oxygen species } \\ \text { SAHA } & \text { Suberoyl anilide hydroxamic acid } \\ \text { SAR } & \text { Structure activity relationship } \\ \text { SD } & \text { Standard deviation } \\ \text { VDA } & \text { Vascular-disrupting agents } \\ \text { ZBG } & \text { Zinc binding group }\end{array}$

\section{References}

1. Ververis, K.; Hiong, A.; Karagiannis, T.C.; Licciardi, P.V. Histone deacetylase inhibitors (HDACIs): Multitargeted anticancer agents. Biol. Targets Ther. 2013, 2013, 47-60. [CrossRef]

2. Choi, J.-H.; Kwon, H.J.; Yoon, B.-I.; Kim, J.-H.; Ham, S.U.; Joo, H.J.; Kim, D.-Y. Expression profile of histone deacetylase 1 in gastric cancer tissues. Cancer Sci. 2001, 92, 1300-1304. [CrossRef]

3. Halkidou, K.; Gaughan, L.; Cook, S.; Leung, H.Y.; Neal, D.E.; Robson, C.N. Upregulation and nuclear recruitment of HDAC1 in hormone refractory prostate cancer. Prostate 2004, 59, 177-189. [CrossRef] [PubMed]

4. Zhang, Z.; Yamashita, H.; Toyama, T.; Sugiura, H.; Omoto, Y.; Ando, Y.; Mita, K.; Hamaguchi, M.; Hayashi, S.; Iwase, H. HDAC6 expression is correlated with better survival in breast cancer. Clin. Cancer Res. 2004, 10, 6962-6968. [CrossRef] [PubMed]

5. Zhu, P.; Martin, E.; Mengwasser, J.; Schlag, P.; Janssen, K.-P.; Göttlicher, M. Induction of HDAC2 expression upon loss of APC in colorectal tumorigenesis. Cancer Cell 2004, 5, 455-463. [CrossRef]

6. Wilson, A.J.; Byun, D.-S.; Popova, N.; Murray, L.B.; L'Italien, K.; Sowa, Y.; Arango, D.; Velcich, A.; Augenlicht, L.H.; Mariadason, J.M. Histone Deacetylase 3 (HDAC3) and other class I HDACs regulate colon cell maturation and p21 expression and are deregulated in human colon cancer. J. Biol. Chem. 2006, 281, 13548-13558. [CrossRef] [PubMed]

7. Khan, O.; La Thangue, N.B. HDAC inhibitors in cancer biology: Emerging mechanisms and clinical applications. Immunol. Cell Biol. 2012, 90, 85-94. [CrossRef]

8. Bozorgi, A.H.A.; Zarghi, A. Search for the pharmacophore of histone deacetylase inhibitors using pharmacophore query and docking study. Iran. J. Pharm. Res. 2014, 13, 1165-1172.

9. Wang, J.; Sun, F.; Han, L.; Hou, X.; Pan, X.; Liu, R.; Tang, W.; Fang, H. Design, synthesis, and preliminary bioactivity studies of substituted purine hydroxamic acid derivatives as novel histone deacetylase (HDAC) inhibitors. Med. Chem. Commun. 2014, 5, 1887-1891. [CrossRef] 
10. Marks, P.A.; Breslow, R. Dimethyl sulfoxide to vorinostat: Development of this histone deacetylase inhibitor as an anticancer drug. Nat. Biotechnol. 2007, 25, 84-90. [CrossRef]

11. Marks, P.A. Discovery and development of SAHA as an anticancer agent. Oncogene 2007, 26, 1351-1356. [CrossRef] [PubMed]

12. Poole, R.M. Belinostat: First global approval. Drugs 2014, 74, 1543-1554. [CrossRef] [PubMed]

13. Garnock-Jones, K.P. Panobinostat: First global approval. Drugs 2015, 75, 695-704. [CrossRef] [PubMed]

14. Mottamal, M.; Zheng, S.; Huang, T.; Wang, G. Histone deacetylase inhibitors in clinical studies as templates for new anticancer agents. Molecules 2015, 20, 3898-3941. [CrossRef] [PubMed]

15. Fantin, V.R.; Richon, V.M. Mechanisms of resistance to histone deacetylase inhibitors and their therapeutic implications. Clin. Cancer Res. 2007, 13, 7237-7242. [CrossRef]

16. Kong, D.; Ahmad, A.; Bao, B.; Li, Y.; Banerjee, S.; Sarkar, F.H. Histone deacetylase inhibitors induce epithelial-to-mesenchymal transition in prostate cancer cells. PLoS ONE 2012, 7, e45045. [CrossRef] [PubMed]

17. Schobert, R.; Biersack, B. Multimodal HDAC inhibitors with improved anticancer activity. Curr. Cancer Drug Targets 2018, 18, 39-56. [CrossRef]

18. Negi, A.S.; Gautam, Y.; Alam, S.; Chanda, D.; Luqman, S.; Sarkar, J.; Khan, F.; Konwar, R. Natural antitubulin agents: Importance of 3,4,5-trimethoxyphenyl fragment. Bioorg. Med. Chem. 2015, 23, 373-389. [CrossRef]

19. Bates, D.; Eastman, A. Microtubule destabilising agents: Far more than just antimitotic anticancer drugs: MDA mechanisms of action. Br. J. Clin. Pharmacol. 2017, 83, 255-268. [CrossRef]

20. Kim, J.H.; Yoon, E.-K.; Chung, H.-J.; Park, S.-Y.; Hong, K.-M.; Lee, C.-H.; Lee, Y.-S.; Choi, K.; Yang, Y.; Kim, K.; et al. P53 acetylation enhances taxol-induced apoptosis in human cancer cells. Apoptosis 2013, 18, 110-120. [CrossRef]

21. Zuco, V.; De Cesare, M.; Cincinelli, R.; Nannei, R.; Pisano, C.; Zaffaroni, N.; Zunino, F. Synergistic antitumor effects of novel HDAC inhibitors and paclitaxel in vitro and in vivo. PLoS ONE 2011, 6, e29085. [CrossRef] [PubMed]

22. Chobaninan, N.H.; Greenberg, V.L.; Gass, J.M.; Desimone, C.P.; Van Nagell, J.R.; Zimmer, T.G. Histone deacetylase inhibitors enhance paclitaxel-induced cell death in ovarian cancer cell lines independent of p53 status. Anticancer Res. 2004, 24, 539-546.

23. Zhang, X.; Zhang, J.; Tong, L.; Luo, Y.; Su, M.; Zang, Y.; Li, J.; Lu, W.; Chen, Y. The discovery of colchicine-SAHA hybrids as a new class of antitumor agents. Bioorg. Med. Chem. 2013, 21, 3240-3244. [CrossRef] [PubMed]

24. Zhang, X.; Kong, Y.; Zhang, J.; Su, M.; Zhou, Y.; Zang, Y.; Li, J.; Chen, Y.; Fang, Y.; Zhang, X.; et al. Design, synthesis and biological evaluation of colchicine derivatives as novel tubulin and histone deacetylase dual inhibitors. Eur. J. Med. Chem. 2015, 95, 127-135. [CrossRef] [PubMed]

25. Yang, Z.; Wang, T.; Wang, F.; Niu, T.; Liu, Z.; Chen, X.; Long, C.; Tang, M.; Cao, D.; Wang, X.; et al. Discovery of selective histone deacetylase 6 inhibitors using the quinazoline as the cap for the treatment of cancer. J. Med. Chem. 2016, 59, 1455-1470. [CrossRef] [PubMed]

26. Wang, L.; Woods, K.W.; Li, Q.; Barr, K.J.; McCroskey, R.W.; Hannick, S.M.; Gherke, L.; Credo, R.B.; Hui, Y.-H.; Marsh, K.; et al. Potent, orally active heterocycle-based combretastatin A-4 analogues: Synthesis, structure-activity relationship, pharmacokinetics, and in vivo antitumor activity evaluation. J. Med. Chem. 2002, 45, 1697-1711. [CrossRef] [PubMed]

27. Schobert, R.; Biersack, B.; Dietrich, A.; Effenberger, K.; Knauer, S.; Mueller, T. 4-(3-Halo/Amino-4,5-dimethoxyphenyl)-5-aryloxazoles and - $\mathrm{N}$-methylimidazoles that are cytotoxic against combretastatin A resistant tumor cells and vascular disrupting in a cisplatin resistant germ cell tumor model. J. Med. Chem. 2010, 53, 6595-6602. [CrossRef]

28. Atuegbu, A.; Solas, D.; Hurt, C.; Kitaygorodskyy, A. 2-phenethenyltetrahydro isoquinolines useful as anti-HIV compounds. WO Patent WO2016100391A1, 23 June 2016.

29. Greene, L.M.; Wang, S.; O’Boyle, N.M.; Bright, S.A.; Reid, J.E.; Kelly, P.; Meegan, M.J.; Zisterer, D.M. Combretazet-3 a novel synthetic cis-stable combretastatin A-4-azetidinone hybrid with enhanced stability and therapeutic efficacy in colon cancer. Oncol. Rep. 2013, 29, 2451-2458. [CrossRef]

30. Huber, S.; Wege, A.K.; Bernhardt, G.; Buschauer, A.; Brockhoff, G. Topotecan-induced ABCG2 expression in MCF-7 cells is associated with decreased CD24 and EpCAM expression and a loss of tumorigenicity: CD24/EpCAM and tumorigenicity of MCF-7 cells. Cytometry A 2015, 87, 707-716. [CrossRef] 
31. Forgue-Lafitte, M.-E.; Coudray, A.-M.; Bréant, B.; Mešter, J. Proliferation of the human colon carcinoma cell line HT29: Autocrine growth and deregulated expression of the c-Myc oncogene. Cancer Res. 1989, 49, 6566-6571.

32. Sutherland, R.L.; Hall, R.E.; Taylor, I.W. Cell proliferation kinetics of MCF-7 human mammary carcinoma cells in culture and effects of tamoxifen on exponentially growing and plateau-phase cells. Cancer Res. 1983, 43, 3998-4006. [PubMed]

33. Mahal, K.; Biersack, B.; Caysa, H.; Schobert, R.; Müller, T. Combretastatin A-4 derived imidazoles show cytotoxic, antivascular, and antimetastatic effects based on cytoskeletal reorganisation. Investig. New Drugs 2015, 33, 541-554. [CrossRef] [PubMed]

34. Mahal, K.; Schruefer, S.; Steinemann, G.; Rausch, F.; Schobert, R.; Biersack, B.; Höpfner, M. Biological evaluation of 4,5-diarylimidazoles with hydroxamic acid appendages as novel dual mode anticancer agents. Cancer Chemother. Pharmacol. 2015, 75, 691-700. [CrossRef]

35. Aldana-Masangkay, G.I.; Sakamoto, K.M. The role of HDAC6 in cancer. J. Biomed. Biotechnol. 2011, 2011, 875824. [CrossRef]

36. Ropero, S.; Esteller, M. The role of histone deacetylases (HDACs) in human cancer. Mol. Oncol. 2007, 1, 19-25. [CrossRef]

37. Xu, W.S.; Parmigiani, R.B.; Marks, P.A. Histone deacetylase inhibitors: Molecular mechanisms of action. Oncogene 2007, 26, 5541-5552. [CrossRef] [PubMed]

38. Steinemann, G.; Dittmer, A.; Kuzyniak, W.; Hoffmann, B.; Schrader, M.; Schobert, R.; Biersack, B.; Nitzsche, B.; Höpfner, M. Animacroxam, a novel dual-mode compound targeting histone deacetylases and cytoskeletal integrity of testicular germ cell cancer cells. Mol. Cancer Ther. 2017, 16, 2364-2374. [CrossRef] [PubMed]

39. Tojkander, S.; Gateva, G.; Lappalainen, P. Actin stress fibers-Assembly, dynamics and biological roles. J. Cell Sci. 2012, 125, 1855-1864. [CrossRef]

40. Kanthou, C.; Tozer, G.M. The tumor vascular targeting agent combretastatin A-4-phosphate induces reorganization of the actin cytoskeleton and early membrane blebbing in human endothelial cells. Blood 2002, 99, 2060-2069. [CrossRef]

41. Mahal, K.; Resch, M.; Ficner, R.; Schobert, R.; Biersack, B.; Mueller, T. Effects of the tumor-vasculature-disrupting agent verubulin and two heteroaryl analogues on cancer cells, endothelial cells, and blood vessels. ChemMedChem 2014, 9, 847-854. [CrossRef]

42. Mahal, K.; Biersack, B.; Schobert, R. New Oxazole-bridged combretastatin A-4 analogues as potential vascular-disrupting agents. Int. J. Clin. Pharmacol. Ther. 2013, 51, 41-43. [CrossRef] [PubMed]

43. Kim, Y.B.; Ki, S.W.; Yosnida, M.; Horinouchi, S. Mechanism of cell cycle arrest caused by histone deacetylase inhibitors in human carcinoma cells. J. Antibiot. (Tokyo) 2000, 53, 1191-1200. [CrossRef] [PubMed]

44. Finzer, P.; Kuntzen, C.; Soto, U.; zur Hausen, H.; Rösl, F. Inhibitors of histone deacetylase arrest cell cycle and induce apoptosis in cervical carcinoma cells circumventing human papillomavirus oncogene expression. Oncogene 2001, 20, 4768-4776. [CrossRef] [PubMed]

45. Kanthou, C.; Greco, O.; Stratford, A.; Cook, I.; Knight, R.; Benzakour, O.; Tozer, G. The tubulin-binding agent combretastatin A-4-phosphate arrests endothelial cells in mitosis and induces mitotic cell death. Am. J. Pathol. 2004, 165, 1401-1411. [CrossRef]

46. Halperin, I.; Ma, B.; Wolfson, H.; Nussinov, R. Principles of docking: An overview of search algorithms and a guide to scoring functions. Proteins Struct. Funct. Genet. 2002, 47, 409-443. [CrossRef] [PubMed]

47. Gaspari, R.; Prota, A.E.; Bargsten, K.; Cavalli, A.; Steinmetz, M.O. Structural basis of cis- and trans-combretastatin binding to tubulin. Chem 2017, 2, 102-113. [CrossRef]

48. Schärfer, C.; Schulz-Gasch, T.; Ehrlich, H.-C.; Guba, W.; Rarey, M.; Stahl, M. Torsion angle preferences in druglike chemical space: A comprehensive guide. J. Med. Chem. 2013, 56, 2016-2028. [CrossRef]

49. Guba, W.; Meyder, A.; Rarey, M.; Hert, J. Torsion library reloaded: A new version of expert-derived SMARTS rules for assessing conformations of small molecules. J. Chem. Inf. Model. 2016, 56, 1-5. [CrossRef]

50. Hai, Y.; Christianson, D.W. Histone deacetylase 6 structure and molecular basis of catalysis and inhibition. Nat. Chem. Biol. 2016, 12, 741-747. [CrossRef]

51. Watson, P.J.; Millard, C.J.; Riley, A.M.; Robertson, N.S.; Wright, L.C.; Godage, H.Y.; Cowley, S.M.; Jamieson, A.G.; Potter, B.V.L.; Schwabe, J.W.R. Insights into the activation mechanism of class I HDAC complexes by inositol phosphates. Nat. Commun. 2016, 7, 11262. [CrossRef] 
52. Mahal, K.; Kahlen, P.; Biersack, B.; Schobert, R. 4-(1-Ethyl-4-anisyl-imidazol-5-yl)-N-hydroxycinnamide-A new pleiotropic HDAC inhibitor targeting cancer cell signalling and cytoskeletal organisation. Exp. Cell Res. 2015, 336, 263-275. [CrossRef] [PubMed]

53. Mosmann, T. Rapid colorimetric assay for cellular growth and survival: Application to proliferation and cytotoxicity assays. J. Immunol. Methods 1983, 65, 55-63. [CrossRef]

54. Höpfner, M.; Sutter, A.P.; Huether, A.; Schuppan, D.; Zeitz, M.; Scherübl, H. Targeting the epidermal growth factor receptor by gefitinib for treatment of hepatocellular carcinoma. J. Hepatol. 2004, 41, 1008-1016. [CrossRef] [PubMed]

55. Berman, H.M.M.; Westbrook, J.; Feng, Z.; Gilliland, G.; Bhat, T.N.; Weissig, H.; Shindyalov, I.N.; Bourne, P.E. The protein data bank. Nucleic Acids Res. 2000, 28, 235-242. [CrossRef] [PubMed]

56. Schmitt, F.; Gold, M.; Begemann, G.; Andronache, I.; Biersack, B.; Schobert, R. Fluoro and pentafluorothio analogs of the antitumoral curcuminoid EF24 with superior antiangiogenic and vascular-disruptive effects. Bioorg. Med. Chem. 2017, 25, 4894-4903. [CrossRef] [PubMed]

57. Rarey, M.; Wefing, S.; Lengauer, T. Placement of medium-sized molecular fragments into active sites of proteins. J. Comput. Aided Mol. Des. 1996, 10, 41-54. [CrossRef] [PubMed]

58. Schneider, N.; Lange, G.; Hindle, S.; Klein, R.; Rarey, M. A consistent description of HYdrogen bond and DEhydration energies in protein-ligand complexes: Methods behind the HYDE scoring function. J. Comput. Aided Mol. Des. 2013, 27, 15-29. [CrossRef]

59. DeLano, W. PyMOL: An open-source molecular graphics tool. CCP4 Newsl. Protein Crystallogr. 2002, 40, $44-53$.

(C) 2019 by the authors. Licensee MDPI, Basel, Switzerland. This article is an open access article distributed under the terms and conditions of the Creative Commons Attribution (CC BY) license (http://creativecommons.org/licenses/by/4.0/). 